\title{
NEUROFYSIOLOGISESTI PERUSTELLUN SIIRTYMÄTEORIAN KÄYTTÖ MELODIA-ANALYYSISSÄ
}

Gábor Lükőn (1964; 1965) hypoteesin mukaan eurooppalaisesta kansanlaulusta edelleenkin löytyy indoeurooppalaisen kantakansan ${ }^{1}$ käyttämät kuusi pentatonista perusmoodia. Kuluneen kymmenen vuoden tutkimustyöni on paljastanut, että nuo kuusi moodia ovat heksatonaalisia (kuusi intervallia oktaavissa). Hermann von Helmholtzin (1863) mukaan harmoniset sävelet järjestyvät kuulokeskuksessa resonanssiperiaatteen mukaan neuronaalisiksi vasteikseen. Gerald Langnerin (2007) neurofysiologiset tutkimukset pakottavat luopumaan Helmholtzin oletuksesta, jonka mukaan pohjasävelen yläsävelet osallistuvat kuulokeskuksessa sävelkorkeuden määrittämiseen. Langnerin mukaan yläsävelillä ei ole osuutta tässä prosessissa. Sen sijaan pohjasävel aktivoi kuulokeskuksessa hermosolu- eli neuronijoukon, joka vastaa fysikaalista mollisointua. Vasta vuoden 2007 lopussa ratkaisin, miten yhdistää Langnerin neurologinen harmoniateoria ja musiikkianalyysi hyväksyttävästi ja tasapainoisesti. Suurimpana ongelmana oli ollut, miten tehdä melodia-analyysiä, jos kuulokeskus luo sävelestä vain mollirakenteisia soluvasteita.

Lükő tunnisti kuusi moodiaan tutkittuaan itäisen Euroopan kansanlauluja sekä hindujen sanskriitinkielisiä veda-sävelmiä (ks. esimerkki 1). Omien tutkimusteni valossa moodit ovat universaaleja ja muodostavat perustan kaikelle luonnolliselle sävelmistölle (ks. kirjallisuusluettelo). Tällä kertaa en kuitenkaan tarkastele heksatonaalisia moodeja, enkä edes niiden aihioita, joihin laulajat ovat yleensä valinneet vain moodin 1-4 astetta. Tässä keskityn aihioiden aihioille, joita kutsun nimellä alleeli. Termi tarkoittaa, että sävelikkö sisältää modaalisen aineksen, joka voi johtaa useaan eri heksatonaaliseen ja pentatonaaliseen moodiin, mutta laulun rakenne ei salli tämän kummempaa määritystä. Alleelit ovat siis aina esimodaalisia, mutta ne ovat kuitenkin ihmisen erilaisten musiikkiperinteiden perusaineksena. Maapallolla varsinaisia heksatonaalisia alueita ovat ennen kaikkea seemiläisten, kaukasuslaisten ja indoeurooppalaisten kansojen elinalueet. Toisaalta alleelit kuuluvat edelleen myös länsimaiseen populaari- ja taidemusiikkiin, joten aihion ja alleelin käsitteet 
eivät viittaa primitiivisyyteen. Esimerkissä 1 Lükőn kuusi kantamoodia on järjestettynä pareittain symboleinaan roomalainen numero. Aihiot tulen merkitsemään samoilla numeroilla mutta lisättynä tähdellä: *I, *III, *VI ja niin edelleen. Tähti kuuluu myös alleeleihin.

Asteiden numerointi myötäilee tonaalista merkintätapaa. Menetelmän päämääränä on tunnistaa melodian modaalinen syntaksi eli laulun rakennetta ohjaileva periaate, joka on laulajan alitajunnassa. Laulun rakenne muunnetaan symboliketjuksi, minkä jälkeen ketjuja vertaillaan. Menetelmällisesti ensin on tunnistettava soiva sävel, joka borduunasävelen lailla tukee vahvimmin laulettujen sävelten aktivoimia hermosoluja. Tämä sävel on hallitsevan moodin dominantti eli aste 5. Tunnistamisen jälkeen melodia eritellään suhteessa dominanttisäveleen, eikä toonikaan kuten tonaalisessa analyysissä (vrt. Huovinen 2002). Jos laulaja vierailee moodin asteiden 5 ja 6 välissä, liike on merkkinä siitä, että dominantti (ja toonika) on vaihtanut paikkaa, ja tutkijan on tunnistettava uuden dominantin sijainti. Täten melodian syntaksi saadaan esille tutkimalla dominanttisävelen siirtymiä. Tästä alkaen borduunan tapaan soivaa todellista tai teoreettisesti määritettyä dominanttia kutsutaan tutkaksi ja tutkasäveleksi sen vuoksi, että se tutkan lailla auttaa analysoijaa tarkkailemaan ja erittelemään sävelten keskinäisiä suhteita ja keskinäisiä liikkeitä.
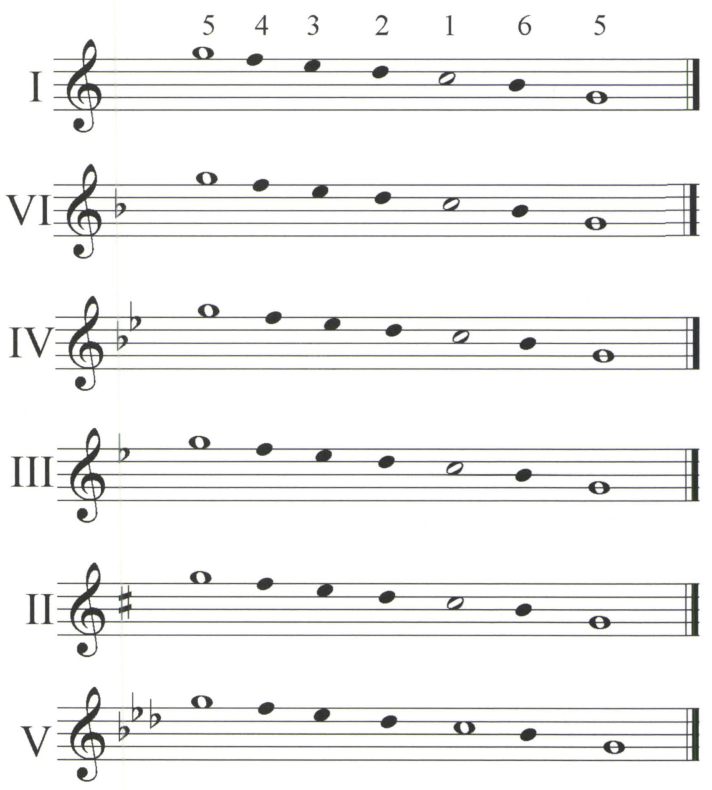

Esimerkki 1. Lükő́n kuusi kantamoodia pareiksi (I+VI; IV+III; II+V) järjestettyinä. Aste 1 on toonika ja 5 on dominantti. Asteiden 6 ja 5 välissä ei ole säveltä. Kun dominantti on sävelellä $g^{1}$, moodit ovat G-horisontissa. Kantamoodit nimetään dominanttisävelensä mukaan: g-I, g-VI, g-III jne. 
Langnerin (2007) teorian mukaan tutkasävel tukee kaikkein vahvimmin laulettuja asteita 5, 6, 1, 2 ja 3. Neljättä astetta se tukee heikosti, ja esiintyminen on usein vihje tulevasta modulaatiosta. Tonaalisella tasolla tämä voidaan helposti ymmärtää: C-duurisävelmässä asteet 5, 6, 1, 2 ja 3 voidaan soinnuttaa C-duurisoinnulla, mutta 4. aste vaatii F-duurisointua, jolloin dominanttikin siirtyy g:ltä c:lle. Tämän kummallisemmasta ei tässä ole kyse. Kitaransoittaja ymmärtää asian helposti: kun säestyssointu vaihtuu, myös heksatonaalinen moodi vaihtuu. Säestyssointujen ketju muodostaa sen, jota tässä kutsun syntaksiksi. Sointuketjujen universaali vertailu korvataan tässä moodiketjujen vertailulla. Ero on siinä, että siirtymäteoriassa oleellista ei ole F-duurisoinnun toonika f, vaan sen dominantti c, jolta nousee ensimmäinen heksatonaalinen moodi c-I.

\section{Harmonisen sävelen muuntuminen kuulokuvaksi}

Langnerin (2007) neurofysiologisen harmoniateorian yhtenä keskeisenä väitteenä on, että kuulokeskuksen osaelimet määrittävät säveltason mittaamalla harmonisen värähtelyn ajallisen keston eli värähdyksen yhden periodin. Kuulosoluissa mittaaminen kohdistuu siis pohjasävelen periodiin. Harmoninen pohjasävel aktivoi joukon keskenään subharmonisessa suhteessa olevia hermosoluja. Kuinka monia soluja ensimmäinen siniaalto (pohjasävel) aktivoi, on kysymys, johon ei ole vastausta, mutta musiikkianalyysissä sävelen neuronaalisen vasteen määritykseen riittää 12 aktivoituneen solun muodostava neurosointu, josta lopulta valitaan vain 6 solua (ks. kuva 2).

Äänen kuuleminen aktivoi kuulojärjestelmässä sävelen useita ominaisuuksia (suunnan, voimakkuuden jne.). Langnerin teorialle keskeisessä asemassa on kaksi piirrekarttaa, jotka ovat aivotutkimusmenetelmin paikannettavissa ja kuvannettavissa kuuloaivokuorella, jolla ne asettuvat toisiinsa nähden 90 asteen kulmaan. Toinen eli tonotopia nousee tietoisuuteen kuvana äänenväristä ja toinen eli periodotopia kuvana äänen korkeudesta. Jälkimmäisen määrittämiseen liittyvän analyysiprosessin kuluessa sävelen pohjasävel aktivoi muun muassa keskiaivojen alakukkulassa (colliculus inferior) solut, jotka ovat virittyneet mainitulle pohjasävelelle. Ne puolestaan myötäaktivoivat 11 muuta solua, mikä matemaattisesti tapahtuu yhden ja saman universaalikaavan mukaan kaikkien sävelten vaikutuksesta kaikissa ihmisissä ja myös kaikissa nisäkkäissä, joita Langner on tutkinut. Sama aktivoitumis- ja 


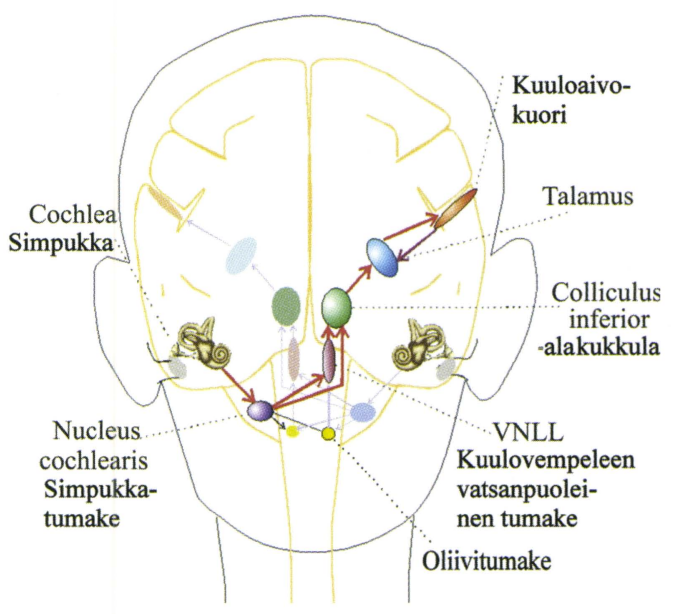

Kuva 1. Kuulokeskus Langnerin (2007: 219, kuva 2) mukaan. Informaatio etenee oikeasta korvasta simpukkaan, simpukkatumakkeeseen ja lopulta vasemmalle kuuloaivokuorelle.

myötäaktivoitumisprosessi toistuu huimalla nopeudella koko kuulojärjestelmän eri tumakkeissa (ks. kuva 1) ja lopulta kuuloaivokuorella.

Fyysisessä maailmassa sävel on harmoninen, kun se koostuu joko jaksollisesta siniaallosta (pohjasävelestä) tai tuosta siniaallosta ja alati lyhenevistä samanaikaisista siniaalloista (yläsävelistä), joiden taajuudet kasvavat kokonaislukujen mukaisina kerrannaisina ${ }^{2}$. Jos pohjasävelen taajuus on $50 \mathrm{~Hz}$, toisen ääneksen (ensimmäisen yläsävelen) taajuus on $2 \times 50 \mathrm{~Hz}$, kolmannen ääneksen taajuus on $3 \times 50 \mathrm{~Hz}$ ja niin edelleen. Täten siis 12 ensimmäisen ääneksen harmonisesti järjestyneet taajuudet (korkeudet) kasvavat sarjana, jossa pohjasävel kerrannaisineen on kursivoitu: 50 100-150-200-250-300-350-400-450-500-550-600-650-700-750-800 Hz.

Langnerin (2007) mukaan kuulokeskuksen elinten monimutkainen analyysi seuraa täsmälleen samaa harmonista logiikkaa, mutta käänteisesti eli subharmonisesti: lähtöarvo jaetaan mainituilla kokonaisluvuilla: 50, 50/2, 50/3, 50/4 ja niin edelleen. Lisäksi Langner on todennut, että kuulosoluissa tapahtuu subharmoninen reaktio riippumatta siitä, liittyykö soivaan säveleen yläsäveliä vaiko ei. Tämä tarkoittaa, että vain fysikaalinen pohjasävel aktivoi sille virittyneen hermosolun, joka puolestaan aktivoi ympäristönsä muita soluja. Yläsävelillä ei sävelkorkeuden tajuamisessa ole merkitystä.

Langner (2007: 231) on toistaiseksi julkaissut vain laskentakaavan, jonka mukaan frekvenssi f aktivoi hermosoluja: $f-f / 2-f / 3$ ja niin poispäin. Hermosolujen näin syntyvä aktivoituminen tuottaa pohjasävelelle mollimuotoisen hermovasteen: sävel c aktivoi neurosoinnun F-molli. Itse tarkastelen subharmonisesti aktivoituneita solupisteitä 1-12. Ilmaus solu on oikeastaan kielikuva, sillä laulu aktivoi rinnakkaisten 
solujen kapeahkon solukaistan ja sen oktaavikerrannaiset. Lisäksi suomen kielellä on hankala puhua subharmonioista, kun tarkoitetaan tietyillä etäisyyksillä toisistaan olevia solukaistoja. Sen vuoksi käytän tässä ilmausta alapiste: jokainen alapiste on solukaista, jonka etäisyys sekä edelliseen että sitä seuraavaan kaistaan määräytyy subharmonisen säännön mukaan. Tämä tulee ymmärrettäväksi kuvan 2 avulla. Siinä ylempänä on fysikaalinen pohjasävel c, joka on merkitty numerolla 1 . Sen harmoniset äänekset 2-12 jatkuvat vasemmalle. Alla on pohjasävelen c aktivoima neuronaalinen C-kaista ja sen subharmonisesti myötäaktivoimat kaistat eli alapisteet 2-12. Kuten Langnerin julkaisemista kuvista (2007: 226-228, kuvat 6-8) havaitaan, aktivaatiotaso on vahvin ensimmäisessä solupisteessä ja heikkenee mitä etäämpänä muut aktivaatiopisteet siitä sijaitsevat.

Kuvan 2 alarivillä näkyvät kaistat, jotka aktivoituvat sävelen c värähdellessä ilman yläsäveliä. Langner tarkastelee alapisteiden välisiä suhteita oman tutkimusmenetelmänsä vuoksi taajuuksina hertseinä. Alapisteiden välisiä matkaeroja voidaan tarkastella logaritmisesti myös centti- eli ellis-yksikön avulla ${ }^{3}$, mikä on musiikintutkijalle tutumpaa. Kuvasta havaitsee, että c-sävel aktivoi kahden keskeisen fysikaalisen soinnun soluvasteet, joista aktivaatiotasoltaan vahvempi on mollimuotoinen sekstisointu Fm6 (D+F-As-C) ja heikompi on duurimuotoinen septimisointu B7 (B$\mathrm{D}^{+}$-F-As).

Musiikkianalyysin kannalta aivan keskeistä Langnerin teoriassa on selitys siitä, miten ihminen kokee sävelkorkeudet musiikin soidessa. Kuulokeskus on täynnään soluissa tapahtuvia sähköisiä jännitepiikkejä (impulsseja) ja tiettyjen yhteensattumasolujen tehtävänä on tunnistaa piikit, jotka toteutuvat samanaikaisesti ja samatahtisesti. Kuulijaa ei häiritse, vaikka vierekkäiset kaistat D-Es-E-F-Ges olisivat samanaikaisesti aktivoituina. Fysikaalisena sointuna tällainen kombinaatio on vahva dissonanssi, mutta kuulojärjestelmä sivuuttaa sen, koska yhteensattumaneuronit tunnistavat kaaoksesta vain yhden samanaikaisen impulssin. Tuo ainoa ja kolmella eri solualueella tapahtuva samanaikainen impulssi nousee tietoisuuden tasolle, mutta solutason monimuotoinen "dissonanssi" jää tiedostamatta.

Tätä voidaan käyttää hyväksi tutkittaessa, mitä kuulokeskuksessa tapahtuu melodian edetessä säveleltä seuraavalle. Prosessia voi seurata sijoittamalla jokaisen sävelen yhteyteen sen aktivoimat neuronaaliset alapisteet ja tutkimalla, mitkä pisteet pysyvät aktiivisina useamman perättäisen sävelen aikana. Erittely ei ole musiikkianalyysin päämäärä, vaan väline, jonka avulla tutkija pääsee syvemmälle pyrkimyksessään ymmärtää, miten melodia vaikuttaa kuulokeskuksen soluihin ja miten tätä kautta saatu 
tieto selittää melodisia prosesseja. Perinteisesti näitä prosesseja on pyritty selittämään akustiikan (yläsävelten) avulla, mutta neurofysiologian näkökulmasta selitys ei ole tyhjentävä. Fysikaalisen (soitetun, lauletun) sävelen avulla voidaan kuvailla prosessi, mutta ei selittää. Olkoon esimerkkinä joiku Ucca lavač Norjasta (esimerkki 2), joka ikään kuin koostuu C-sävelen laskevista luonnonsävelistä 8, 6 ja 5. Kun se nuotinnetaan niin, että 6. "luonnonsävel" asettuu sävelelle g1, melodia on G-horisontissa.

Joiku voidaan pelkistää sävelliikkeeksi c-g-e-c, joista viimeinen c on uuden säkeen aloitussävel. Kuulokeskuksen vasteprosesseja nähdään kuvassa 3. Vaakariveiltä havaitaan, että joiku pohjaa vahvalle sidonnalle, koska yhtäältä kolme tai neljä

\section{Fysikaalisen $c$-sävelen äänekset 1-12. Lue oikealta vasemmalle.}

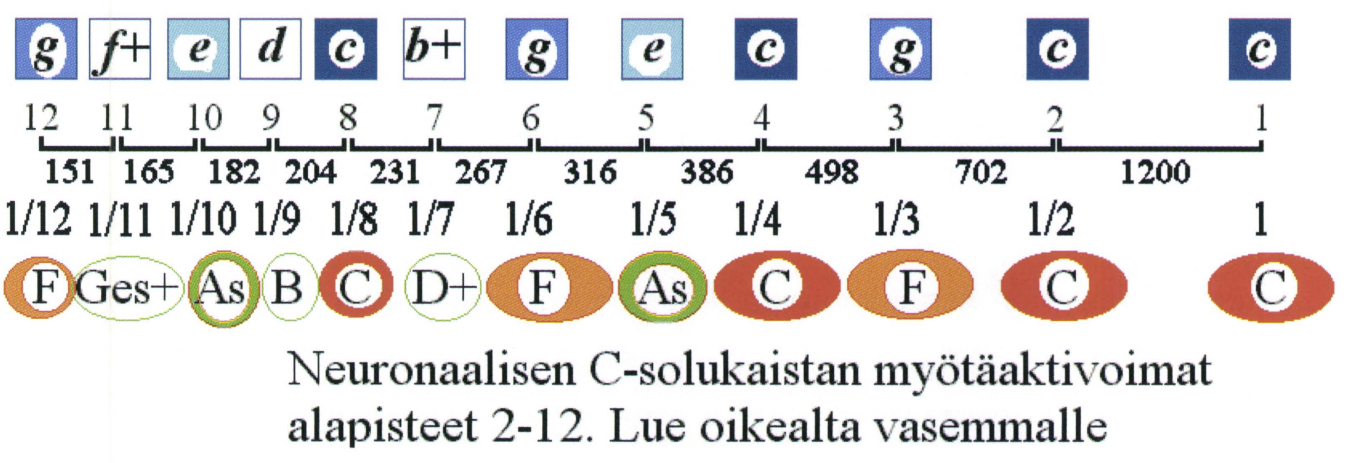

Kuva 2. Yläpuolen neliöissä ovat fysikaaliset äänekset 1-12 nurinkurisessa järjestyksessä oikealta vasemmalle. Sarjan käynnistää oikealla oleva c [1], joka on pohjasävel. Alempana ympyröiden sisässä ovat c-sävelen aktivoimat 12 kaistaa. Kun ylempi sarja rakentuu harmonisesti (1,2x1, 3x1, 4x1 jne.) alempi sarja järjestyy subharmonisesti (1, 1/2, 1/3, 1/4 jne.). Sarjojen välillä olevat pienet luvut kuvaavat sekä fysikaalisten äänesten että neuronaalisten alapisteiden välisiä intervalleja ellis-yksikön avulla: tasavireinen puolisekunti on 100 ellistä, kvintti on 700 ellistä ja oktaavi 1200 ellistä. Harmoniset intervallit eroavat monin paikoin tasavireisistä myös solutasolla. Kuten havaitaan, C-kaista aktivoituu neljässä pisteessä, Fsolu kolmessa, As-solu kahdessa ja loput eli solut $D^{+}, B$ ja Ges ${ }^{+}$vain kerran. Supistettuna fysikaalisen c:n pohjasävelen neuronaalinen vaste on siis (oikealta vasemmalle) $C, A s, F, D^{+}$, $B, G^{+}{ }^{+}$. Toisaalta havaitaan, että sarjassa toistuu kuulosolujen summana kahdesti ikään kuin molliseksisointu Fm6 ( $D^{+}-F-$-As--C) ja kerran duuriseptimisointu B7 (B--D+--F--As). 


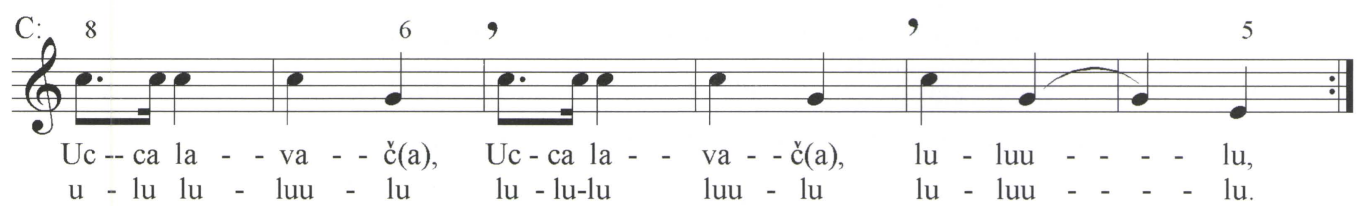

Esimerkki 2. Kolmisävelinen joiku Polmakista koostuu Launiin (1908: 35) mukaan ikään kuin pohjasävelen C luonnonsävelistä 8, 6 ja 5.

solukaistaa sitoo samanaikaisesti jokaisen lauletun sävelen yhdeksi jatkumoksi. Sidoskatkosta ei esiinny. Toisaalta C-kaista on kaiken aikaa ärsytettynä: se toimii alitajuisena ankkurina. C-hermo pysyy aktiivitilassa, koska c-sävelen soidessa se on subharmonisina alapisteinä 1-1/2-1/4-1/8, g-sävel aktivoi sen alapisteissä 1/3, 1/6 ja 1/12, ja e-sävel aktivoi sen alapisteissä 1/5 ja 1/10. (Jatkossa ilmaisen subharmoniset pisteet jakajaan viittaavina kokonaislukuina luettavuuden takia. Myös termi "alapiste" osoittaa niiden subharmonisen luonteen.)

Kuva 3 paljastaa kaksi seikkaa. Ensimmäinen saattaa selittää, miksi laulajien säveltaso pyrkii kaikkialla maapallolla nousemaan, mikäli laulun tukena ei ole kiinteävireistä soitinta. Kun sidonta alkaa 7. alapisteessä (esim. B+ kuvassa 3) ja jatkuu B-kaistalla (kuten tapahtuu joikaajan siirtyessä päätössäveleltä e seuraavan säkeen alkusävelelle c), joikaaja pyrkii alitajuisesti säilyttämään $\mathrm{B}^{+}$-kaistan aktiivitilassa silloin, kun laulettu b-sävel olisi koko joiun sitoman C-ankkurin suhteen lievästi matala. Suhteessa edellisiin b-säveliin uusi b-sävel nousisi lievästi. Termi "lievästi" tarkoittaa kuvan 2 antaman vihjeen mukaan noin pienen sekunnin puolikkaan mittaista nousua siirryttäessä

Kuva 3. Ucca lavač -joiun peräkkäin esiintyvät sävelet ja niiden aktivoimat solukaistat eli alapisteet näkyvät pystysuorina riveinä. Vaakasuorilla riveillä näkyy tummennettuna, mitkä kaistat pysyvät aktiiveina, vaikka laulettu sävel vaihtuu. Kyse on sidonnasta. Sointumerkinnät Fm, Cm ja Am tarkoittavat vahvimmin aktivoituneista kuulosoluista muodostuvia mollimuotoisia neurosointuja. Niitä heikommat duurimuotoiset aktivoituneet neurosoinnut B7, F7 ja D7 (ks. kuva 2) jätetään ekonomisista syistä merkitsemättä.

\begin{tabular}{|c|c|c|c|c|}
\hline Lauletut sävelet: & c & $\mathrm{g}$ & $\mathrm{e}$ & c \\
\hline \multirow{9}{*}{$\begin{array}{l}\text { Soluvasteet } \\
\text { (pystyrivit) } \\
\text { ja sidonta } \\
\text { (vaakarivit): }\end{array}$} & $\mathrm{Fm}$ & $\mathrm{Cm}$ & Am & Fm \\
\hline & C & C & $\mathrm{C}$ & $\mathrm{C}$ \\
\hline & B & & $\mathrm{B}+$ & B \\
\hline & As & & & As \\
\hline & Gest & & Fist & Gest \\
\hline & $\mathrm{F}$ & $\mathrm{F}$ & & $\mathrm{F}$ \\
\hline & & Es & $\mathrm{E}$ & \\
\hline & $\mathrm{D}+$ & & D & D+ \\
\hline & & Dest & & \\
\hline
\end{tabular}


säkeestä seuraavalle. Matemaattisesti nousu olisi runsaat 60 ellistä, mutta kun kyse on laulusta, tarkat määritteet ovat merkityksettömiä. Oleellista on ottaa todesta mahdollisuus, että alapiste 7 saattaa olla yhtenä syynä laulun säveltason lievään nousuun, mitä vastaan meillä varsinkin kuoronjohtajat taistelevat.

Toinen päätelmä liittyy termiin luonnonsävelmelodia. Keskiaasialainen kurkkulaulaja saa matalan rintaäänensä aktivoimat yläsävelet vahvistumaan ja soimaan vihellysmäisinä siniaaltoina. Sen sijaan sormiaukottoman pitkähuilun tai alppitorven sävelet ovat luonnonsäveliä: soittajan lisätessä puhallusvoimaa putkessa syntyy yhä korkeampia säveliä, joiden keskinäiset suhteet noudattavat harmonista periaatetta (f, 2f, 3f jne.), mutta jokainen uusi sävel on oma itsenäinen sävelensä omine yläsävelineen. Sekä ylä- että luonnonsävelten välisillä matemaattisilla suhteilla on täsmälliset vastineensa kuulokeskuksen subharmonisissa alapisteissä. Esimerkin 2 äänesten 8-6-5 (c-g-e) vasteet ovat neuronaaliset alapisteet 8-6-5 (C-F-As). Tämä ei kuitenkaan voi selittää sitä, että tietyillä seuduilla ihminen laulaa luonnonsäveliä mukailevia melodioita. Niiden suosion syy löytyneekin siitä, että lauletut sävelet ovat samanaikaisesti monen solukaistan sitomia ja kaistoista yksi muodostaa varsin tukevan neuronaalisen (alitajuisen) ankkurin.

Luonnollisessa G-horisontissa ankkuri on neuronaalisella C-kaistalla (kuva 3), ja ankkurin fysikaalisen vasteena on aina moodin toonika. Onkin syytä siirtyä tarkastelemaan heksatonaalisten moodien universaaleja alleeja. Olen päätynyt ratkaisuun, jonka mukaan nämä esimodaaliset alleelit, joita ei voi modaalisesti määrittää, nimetään kreikkalaisten kirjainten avulla.

\section{Avoin alfa-alleeli: ${ }^{\star} a$}

Maapallolla on rudimentaalinen sävelikkö, jonka sävelsuhteet ovat kuten luonnonsävelillä 6-8-9-10. Tällainen avoin alleeli (g-c-d-e) tarkoittaa säveljoukkoa, jonka modaliteettia ei voi määrittää, koska toonikan c ja alapuolisen g-dominantin välissä ei ole yhtään säveltä. Avoin kanta-alleeli on siis esimodaalinen. Alleelin symbolina on aina tähti, joten rakenteen $\mathrm{g}-\mathrm{c}$-d-e mukaisen alleelin universaalisymboliksi voidaan sopia kreikkalainen kirjain alfa: ${ }^{*} \alpha$. Kun alleeli on G-horisontissa, laulun syntaksia kuvaa g-* $\alpha$. Tällaisen symbolin käyttö helpottaa globaalia vertailua, koska analyysiaineistosta alleelin erilaiset ilmentymät voidaan koota helposti. Missä tahansa sen tapaa ja minkälaisen tahansa kulttuurin edustaja sen laulaa, alleelin säve- 
let saavat saman vasteen ihmisen kuuloaivoissa (kuva 4).

Kuvista 3 ja 4 paljastuu, että G-horisontissa alitajuisena ankkurina on C-neuroni. Universaalisti voidaan sanoa, että alfa-alleelin aikana pohjasävelen c aktivoima Ckaista pysyy kuulokeskuksessa muidenkin laulettujen sävelten vuoksi ärsytystilassa. Käytännössä sävel, joka tukee C-solua on g-tutka, jonka Cm-soluvasteen C on tutkan alapisteinä 3, 6 ja 12: kuulokeskuksen kannalta optimaalisin tutkasävel on toonikan aktivoimia alapisteitä 1, 2, 4 ja 8 tukeva dominanttisävel. Neurofysiologian kannalta vahvin tutka on siis aina kvarttia alempana kuin toonika.

Esimerkissä 3A on inarilainen joiku, joka alkaa toonikalla ja päättyy dominantille $\left(\mathrm{g}-{ }^{*} \alpha^{1 \rightarrow}{ }_{5}\right){ }^{4}$ Esimerkki 3B alkaa dominantilla ja päättyy toonikalle $\left(\mathrm{g}^{-*} \alpha_{5} \rightarrow 1\right)$. Kyse on havaijilaisen hulan loppusäkeestä, jonka muuntelevaan toistoon laulu rakentuu. Keskeisimpänä sitojasoluna (SN) on sama kuin edellisessä eli C-solu. Alaviivastolla nähdään laulettujen sävelten aktivoimia hermosoluja kuin sointuina. Sävelmä $3 \mathrm{C}$ on keettien ${ }^{5}$ mytologiaan kuuluvan laulun kertautuva perussäe, joka alkaa alfa-alleelin 3. asteelta ja etenee aladominantin kautta toonikaan. Lauluopillisena kaavana on siis - $^{*} \alpha^{3 \rightarrow 1}$.

Alfa-alleeli näyttää vuosituhansien kuluessa siirtyneen Siperiasta Kanadaan ja lopulta Grönlantiin vaeltaneiden inuittien mukana. Esimerkin 3D alleelin rakenne

\begin{tabular}{|c|c|c|c|c|c|}
\hline Astect: & 5 & 1 & 2 & 3 & 5 \\
\hline Lauletut sävelet: & $\mathrm{g}$ & c & d & $\mathrm{e}$ & $\mathrm{g}$ \\
\hline Vasteen symboli: & $\mathrm{Cm}$ & $\mathrm{Fm}$ & $\mathrm{Gm}$ & $\mathrm{Am}$ & $\mathrm{Cm}$ \\
\hline \multirow{10}{*}{$\begin{array}{c}\text { Soluvaste } \\
\text { eli } \\
\text { neurosointu } \\
\text { (pystysuora) } \\
\text { ja } \\
\text { sidonta } \\
\text { (vaakasuora) }\end{array}$} & $\bar{C}$ & $\bar{C}$ & C & C & C \\
\hline & \multirow{3}{*}{$\mathrm{A}^{+}$} & B & B & $\mathrm{B}+$ & \\
\hline & & & & A & $\mathrm{A}+$ \\
\hline & & As & Ast & \multirow{3}{*}{ Fis +} & \multirow[b]{2}{*}{$\mathrm{G}$} \\
\hline & G & Gest & \multirow[t]{2}{*}{$\mathrm{G}$} & & \\
\hline & F & F & & & \multirow[t]{2}{*}{$\mathrm{F}$} \\
\hline & \multirow[b]{2}{*}{ Es } & & $\mathrm{E}+$ & E & \\
\hline & & & & & \multirow[t]{2}{*}{ Es } \\
\hline & \multirow[b]{2}{*}{ Des' +} & $\mathrm{D}+$ & $\mathrm{D}$ & D & \\
\hline & & & & & Des+ \\
\hline
\end{tabular}

Kuva 4. Avoimen alfa-alleelin $\left(g-{ }^{*} \alpha\right)$ sävelet $(g-c-d-e)$ ja niiden vasteet neljänä neurosointuna. Tummennettu sidonta näkyy vaakariveillä, joista C-ankkuri on ylinnä. Solukaistat on tilan säästämiseksi sijoitettu toistensa lomiin. Kun esittäjä laulaa toonikan (c), sen subharmoninen alapiste 7 eli $D+$ saattaa pyrkiä vaikuttamaan niin, että sitä välittömästi seuraava D-solu mukautuu D+:aan, mikä saattaa johtaa säveltason nousuun laulun aikana. Sama koskee lauletun d-sävelen 7. alapistettä E+. Muiden sävelten yhteydessä tällaista ei pääse tapahtumaan, koska plusmerkkien jälkeen sidonta katkeaa. 

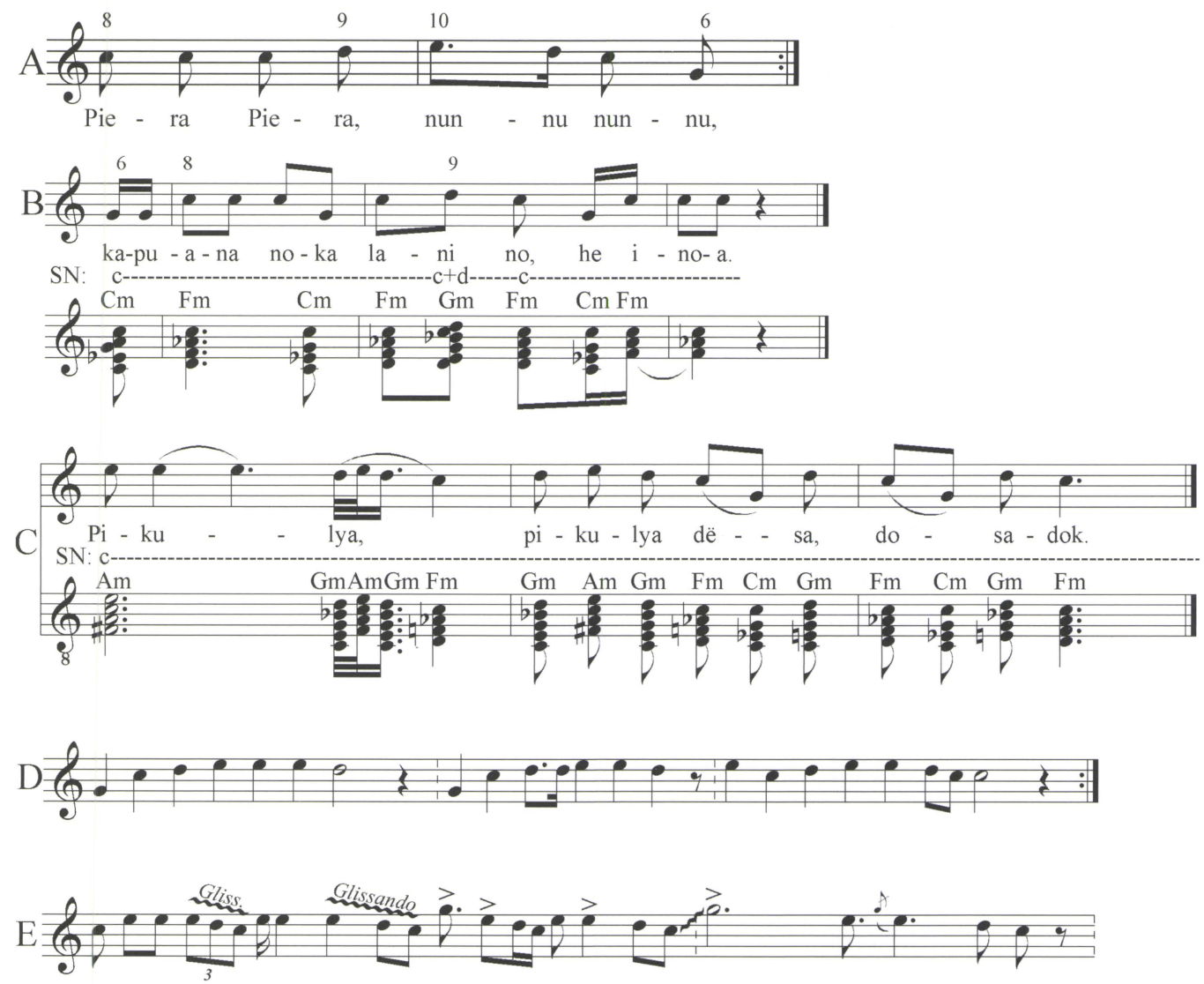

Esimerkki 3. Alfa-alleelille on $g_{-}^{*} \alpha$ pohjaavia sävelmiä. A. Inarilainen Pieran joiku Launiin (1908: 64) mukaan. B. Havaijilaisen hulan säe (Kaeppler 1983: 146; nuotinnos Mary Pukui.) Alaviivastolla näkyy osa kunkin sävelen vasteesta kuulokeskuksessa. Lyhenne SN tarkoittaa sitojasoluja, joista keskeisimmät ovat C ja D. C. Jenisei-joella asuvien keettien lintu-ihmisestä kertovan mytologisen laulun melodiaa Šejkinin (2002: 704, nro 2) mukaan. Alarivillä näkyy osa aktivoituneista hermosoluista. C-solu on kaiken aikaa aktiivitilassa, joten kaikkia laulettuja säveliä tukisi optimaalisesti tutkasävel g. D. Kolme säettä Etelä-Grönlannin surumielisestä eskimolaulusta Hauserin (1992: 94:2) mukaan. E. Kaksi säettä itägrönlantilaisesta pilkkalaulusta Hauserin (1992: 41:2) mukaan. Alleeli on riippuva. 
on g- ${ }^{*} \alpha_{5} \rightarrow 1$, koska melodia käynnistyy dominantilla (aste 5) ja päättyy toonikalle. Esimerkin 3E melodia on niin ikään Grönlannista, mutta edustaa nyt riippuvaa alfaalleelia, koska melodian korkein sävel on dominantin yläoktaavi $\mathrm{g}^{2}$. Ilmaisen riippuvan rakenteen syntaktisissa kaavoissa kreikkalaisella $\pi$-kirjaimella (< latinan pendeō "riippua"), joten syntaksikaavana on g- $\pi^{*} \alpha^{1 \rightarrow 1}$. Nyt voidaan määrittää esimerkissä 2 olevan Ucca lavačin syntaksi, jossa tosin loppusävel on poikkeuksellinen, koska se on dominantin alapuolella oleva aste $3\left(\mathrm{e}^{1}\right)$ : g- $\alpha^{1 \rightarrow}{ }_{3}$.

Esimerkki 4A on ute-väestön hidastempoinen parannuslaulu Utahista. Utet kuuluvat samaan kielikuntaan kuin Väli-Amerikan atsteekit. Heidän kantakulttuurinsa oli jo vuosituhansia sitten siirtynyt pohjoiseen, Suurelle syvänteelle Kalliovuorten eteläpuolella. Uto-atsteekin kielikunnan puhujien esivanhemmat olivat ilmeisesti väestöä, joka oli onnistunut matkaamaan Väli-Amerikkaan jo ennen kuin jäämassat olivat muuttaneet Pohjois-Amerikan mantereen elinkelvottomaksi. Jos näin oli, heidän lauluoppinsa palautuu kymmenien vuosituhansien takaiseen kaakkoisaasialaiseen lauluoppiin, jolla on yhteyksiä protomalaijien lauluoppiin.

Esimerkki 4A edustaa alfa-alleelia, mutta melodian rakenne poikkeaa edellisistä. Esimerkin 3A alleelina on g-* $\alpha^{1 \rightarrow}$ ja esimerkkien 3B ja D alleelina on $\mathrm{g}_{-}{ }^{*} \alpha_{5} \rightarrow 1$. Esimerkin 4A kaava on toinen, mikä paljastuu kuvasta 5. Tässä kohden on tehtävä selväksi fysikaalisen soinnun ja neurosoinnun välinen ero. Fysikaaliset sävelet (kuten C-duurikolmisoinnun sävelet c-e-g) soivat yhdessä harmonisesti. Kuvasta 5 havaitaan, että sävelten c, e ja g yhtä aikaa aktivoimat solukaistat muodostaisivat riitasoinnun, jos ne soitettaisiin pianolla: $\mathrm{D}^{+}-\mathrm{D}-\mathrm{Des}^{+}-\mathrm{C}-\mathrm{B}^{+}-\mathrm{B}-\mathrm{A}^{+}-\mathrm{A}-\mathrm{As}^{+}-\mathrm{G}-\mathrm{Ges}{ }^{+}-\mathrm{F}-\mathrm{E}-\mathrm{Es}$. Tämä ei haittaa kuulijaa, joka ei ole tietoinen kaaoksesta. Kuulojärjestelmän päämääränähän on etsiä "yhteiset nimittäjät". Tätä etsintää varten niin sanotut yhteensattumasolut

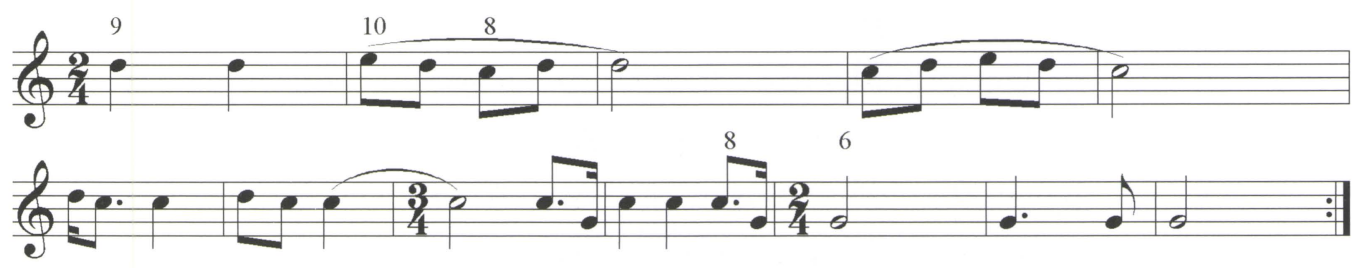

Esimerkki 4A. Tällä laululla Suuren syvänteen ute-väestön parantaja oli Densmoren (1922: 58) mukaan hoitanut sairaita. Kyse on alfa-alleelin g-* $\alpha$ käännöksestä $g-i^{*} \alpha$. Käänteisen moodin keskeinen ominaisuus on nurinkurisesti se, etteivät dominantti- eli tutkasävelen aktivoimat solukaistat tue toonikaa, vaan moodin 2. asteen aktivoimat solukaistat tukevat tutkasäveltä. 


\begin{tabular}{|c|c|c|c|c|c|c|c|}
\hline \multirow{2}{*}{$\begin{array}{l}\text { Laulettu sävel: } \\
\text { Hermosointu: }\end{array}$} & $\bar{d}$ & e & $\bar{d}$ & c & $\mathrm{d}$ & c & $\mathrm{g}$ \\
\hline & $\mathrm{Gm}$ & $\mathrm{Am}$ & $\mathrm{Gm}$ & $\mathrm{Fm}$ & $\mathrm{Gm}$ & $\mathrm{Fm}$ & $\mathrm{Cm}$ \\
\hline \multirow{10}{*}{$\begin{array}{l}\text { Vaste } \\
\text { ja } \\
\text { sidonta: }\end{array}$} & $\mathrm{D}$ & $\mathrm{D}$ & $\mathrm{D}$ & $\mathrm{D}+$ & $\mathrm{D}$ & $\mathrm{D}+$ & \multirow[b]{2}{*}{ Dest } \\
\hline & & & & & & & \\
\hline & C & C & C & C & C & C & C \\
\hline & B & $\mathrm{B}+$ & B & B & B & B & \multirow{4}{*}{$\mathrm{A}+$} \\
\hline & \multirow{4}{*}{$\begin{array}{l}\mathrm{As}+ \\
\mathrm{G}\end{array}$} & \multirow[t]{3}{*}{ A } & & & & & \\
\hline & & & $\mathrm{As}$ & $\mathrm{As}$ & $\mathrm{As}+$ & $\mathrm{As}$ & \\
\hline & & & $\bar{G}$ & \multirow{4}{*}{$\begin{array}{l}\text { Ges }+ \\
\mathrm{F}\end{array}$} & $\mathrm{G}$ & Gest & \\
\hline & & Fis + & & & \multirow{3}{*}{$\mathrm{E}+$} & $\mathrm{F}$ & $\mathrm{F}$ \\
\hline & $\mathrm{E}+$ & E & $\mathrm{E}+$ & & & & \multirow[b]{2}{*}{$\mathrm{Es}$} \\
\hline & & & & & & & \\
\hline
\end{tabular}

Kuva 5. Nuottiesimerkin $4 A$ sävelmän aktivoimat solut kuulokeskuksessa. Sidonta näkyy vaakasuoraan. Kuulokeskuksen aktivoitumiskuvissa käytetään tästä alkaen kuvaustapaa, jonka mukaan alapisteet 1-8, 10 ja 12 ilmaistaan suurilla kirjaimilla, alapisteet 9 ja 11 pienillä kirjaimilla. Sävel c aktivoi solukaistat C-F-As- $D^{+}$, joista viimeisintä seuraava plus osoittaa, että kyseessä on alapiste 7. Pienillä kirjaimilla ilmaistaan alapisteet 9 ja 11, joista jälkimmäisellä on plusmerkki. Tässä tapauksessa alapiste 9 on b ja alapiste 11 on ges+. Kun sarjassa C-F-As- $D^{+}-b$-ges ${ }^{+}$aktivoitumisen voimakkuus heikkenee vasemmalta oikealle, vaakasuorista sidosriveistä saa visuaalisen yleiskuvan solupisteiden aktivoitumisen suhteellisista voimakkuuksista. Vahvinta sidosriviä kutsun neuronaaliseksi ankkuriksi. Sen sävelvasteena on toonika.

(ks. Langner 2007: 222, kuva 3) aktivoituvat vain silloin, kun niissä tapahtuvat sähköpiikit (impulssit) osuvat täsmälleen samassa hetkessä kuin kahdessa muussakin elimessä tapahtuvat impulssit. Vain tämän samanaikaisuuden ja samatahtisuuden tunnistaminen sisältää sen informaation, joka siirtyy aivokuorelle kuvana sävelkorkeudesta. Aivot mittaavat piikkienvälisen ajan, mutta kuulojärjestelmässä tapahtuvat prosessit sallivat myös periodien huojunnan eli muuntelun. Muutoin ihminen ei kykenisi tajuamaan vibratona etenevää ääntä yhdeksi sävelkorkeudeksi. Piikkien välisten aikavälien määritys tekee mahdolliseksi sidonnan (joka näkyy vaakasuorina tummennettuina alueina kuvassa 5) ja toisaalta tekee mahdolliseksi senkin, että - kuten arvelen - kuulokeskus käsittelee hermokaistoja $\mathrm{D}^{+}$ja D saman periodin muunnoksina.

Jos melodia alkaa sävelellä c², alfa-alleelin kaikki sävelet aktivoivat C-kaistan ja sen oktaavikerrannaiset. Niistä muodostuu kuulokeskuksessa vahva ankkuri. Esi- 


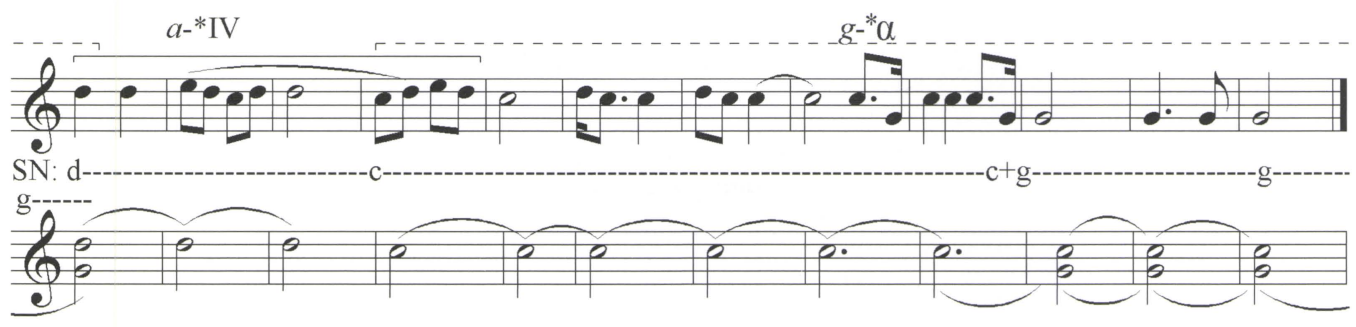

Esimerkki 4B. Ute-laulun sävelet aktivoivat vahvimmin solualueet D, C ja G.

merkin 4A tilanteessa ensisävelenä ei kuitenkaan ole $c^{2}$ vaan $\mathrm{d}^{2}$, joka aktivoi neurosoinnun Gm eli laskevasti solukaistat D-B-G-E $-\mathrm{E}^{+} \mathrm{C}-\mathrm{As}^{+}$oktaavikerrannaisineen. Mitä etäämmällä aktivoinut solukaista on ensireaktiosta $G$, sitä vähäisempi on sen energia. Tämän pohjalta olen alustavasti laskenut kullekin 12 alapisteelle sen energiaa kuvaavan suhteellisen aktivoitumisarvon. ${ }^{6}$ Näin ollen kuvasta 5 havaitaan, että alkusävel d $\mathrm{d}^{2}$ aktivoi D-kaistan arvolla 6,2, mutta C-kaistan aktivaatioarvo on vain 1,1. Lauletun sävelen $\mathrm{e}^{2}$ aikana C-kaistan aktivaatio on 2,3, mutta loppusävelen $\mathrm{g}^{1}$ aikana se 3,7. Täten $C$-solut ovat vahvimmillaan vain silloin, kun sävelet $\mathrm{c}^{2} \mathrm{ja}^{1}{ }^{1}$ soivat, jos kohta se on aktivoituneena kaiken aikaa.

Tutkasävel on siis optimaalinen, kun se on sama kuin melodian dominanttisävel aivan riippumatta siitä, esiintyykö itse melodiassa dominanttisäveltä. Se tukee kaikkia laulettuja säveliä. Esimerkin 4B kolmen ensitahdin aikana melodia etenee ikään kuin aihion a*IV (a-c-d-e-f) varassa. Tutkasävelenä olisi siis a, joka tukee laulettuja säveliä. Sävel g asettuu tutkaksi vasta tahdissa 4, kun kuulokeskuksessa vahvimmin aktivoitunut D-neuroni vaihtuu C-neuroniksi. Sävelmän syvärakenne voidaankin kiteyttää kaavaan a-* $\mathrm{IV}^{1} \rightarrow \mathrm{g}^{*} \alpha^{1 \rightarrow}{ }_{5}$. Kun analyysin lähtökohtana on, että melodian aloittava dominantti asettuu sävelelle $\mathrm{g}^{1}$, niin ehtohan ei toteudu. Tässä tullaan keskeiseen teoreettiseen yksityiskohtaan, joka on globaali: kohtaamme ilmiön, jota olen kutsunut moodin käännökseksi. Sen symbolina on käänteinen kysymysmerkki ¿.

Esimerkkiä 4B ei voi sijoittaa G-horisonttiin kuin olettamalla, että aloittava d-sävel on kvinttiä g-tutkan eli dominantin yläpuolella. Tällöin kyse on alfa-alleelin asteesta 2 eli sävelestä $\mathrm{d}^{2}$. Itse sävel g sopii odotuksenmukaisesti tutkaksi, sillä C-kaista on kaiken aikaa ärsytystilassa, vaikkei se ole kaiken aikaa prominentti (kuva 5). Jos siis ulkopuoliseksi tutkaksi valitaan g, syntyy kiintoisa reaktio: lauletun d-sävelen aktivoima neurosointu Gm6 (D-B-G-E -c-as $^{+}$) ei tuekaan toonikaa vaan dominanttia g. Tämä johtuu siitä, että lauletun sävelen d aktivoima G-kaista on prominentti (22), 
kun taas d:n aktivoima C-kaista on heikko (2). Täten G-kaista tukee nimenomaan tutkan pohjasäveltä. Kun tutkan periodi on sama kuin lauletun d-sävelen aktivoimien alapisteiden 3-6-12 periodit ${ }^{7}$, niin tutkan aktivoimat alapisteet 1-2-4-8 tukevat lauletun sävelen alapisteitä 3-6-12, eivätkä suinkaan sen alapisteitä 1-2-4-8. Kun siis g-tutka tukee lauletun d-sävelen aktivoimia alapisteitä 3-6-12, voidaan sanoa, että laulettu sävel tukee tutkaa, mutta tutka ei tue laulettua säveltä. Siis G-horisontti paljastaa, että laulun aloittava rakenne on käänteinen alfa-alleeli g- ${ }^{*} i \alpha$.

Neljännessä tahdissa on selkeä välike. Jälkikäteen kuunneltuna välikkeen tehtävänä on valmistaa muuntamaan käännetty g- ${ }^{*} i \alpha$ luonnolliseksi eli asuun g-* $\alpha$. Kuulija ei voi tätä tietää, vaan olettaa moodin edelleenkin olevan käännetyn, mutta neljännen tahdin jälkeen käy selväksi, että toonikana on c, jota laulaja selkeästi painottaa. Tutkana edelleen soiva g tukee neljännestä tahdista alkaen laulettua c:tä. Säkeen loppupuolella alaspäinen hyppy $\mathrm{c}^{2}-\mathrm{g}^{1}$ on tukeva, vaikkei c-sävel aktivoi Gkaistaa (mutta kylläkin As- ja Ges-kaistat sen kahta puolta). Kuulokeskuksen solujen keskinäinen järjestymissuhde on kuten oktaavi- ja kvinttisuhde. Koska solujen kannalta nousu c:ltä g:lle on sama kuin lasku c:ltä g:lle, fysikaalinen kvarttihyppy alas noudattaa solujen oktaavi-kvintti-suhdetta.

Kun siis melodia käynnistyy d:llä sen aktivoima Gm6 (D-B-G-E'-C-as') alkaa tukea g-ankkuria, jonka aktivoima neurosointu $\mathrm{Cm} 6$ (G-Es-C-A $\mathrm{A}^{+}$-f-des ${ }^{+}$) ei tue kuin solujen G ja C avulla laulettua d-säveltä. Käänteisyyttä voidaan verrata antiikin ajoista tunnettuun sointuun D-G-D (ks. Zarlino 1983). Siinä oktaavi D-D jakautuu alempaan kvarttiin D-G ja ylempään kvinttiin G-D. Kyseessä on "epätäydellinen" oktaavijako. Kun tämä "käännös" oikaistaan "täydelliseksi", syntyy oktaavi D-A-D, jossa alhaalla on kvintti D-A ja ylhäällä kvartti A-D. Esimerkissä 4 käänteinen moodi siis syntyy, kun G-horisontissa melodian keskeisenä sävelenä on aste 2. Se tukee tutkaa, joka ei tue laulettua d:tä. Tilanne on nurinkurinen suhteessa luonnolliseen moodiin, jossa tutka tukee vahvasti toonikaa. Vasta viidennessä tahdissa toonika on selkeästi c.

Kuulija ei voi täysin varmistua tonaalisesta keskuksesta ennen kuin melodia painuu alas viidennelle asteelle g, jonka synnyttämä neurosointu on sama kuin ulkoisen tutkan neurosointu. Tämä ei kuitenkaan pitkäksi aikaa auta, sillä seuraavan säkeen aloitus tapahtuu taas d:Itä ja luonnollinen alfa-alleeli kiepahtaa käänteiseksi alfa-alleeliksi.

Esimerkit 5A ja 5B ovat niin avoimia, että niistä voisi johtaa suuren määrän moodeja. Koska niistä puuttuu sävel b, ne edustavat alfa-alleelia. Juhan Maijan syntaksi on suhteellisen harvinainen pohjoisella pallonpuoliskolla, koska se alkaa dominan- 


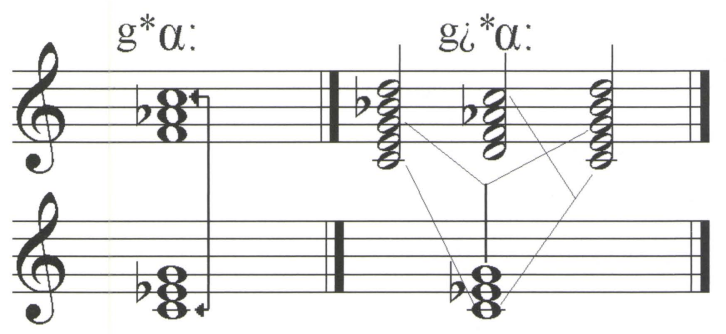

Esimerkki 4C. Ylärivillä näkyy laulettujen sävelten c ja d vahvimmin aktivoimia soluja, alarivillä taas g-tutkan aktivoimia soluja (= neurosointu Cm). Vrt. Esim. 4 A ja 4B.
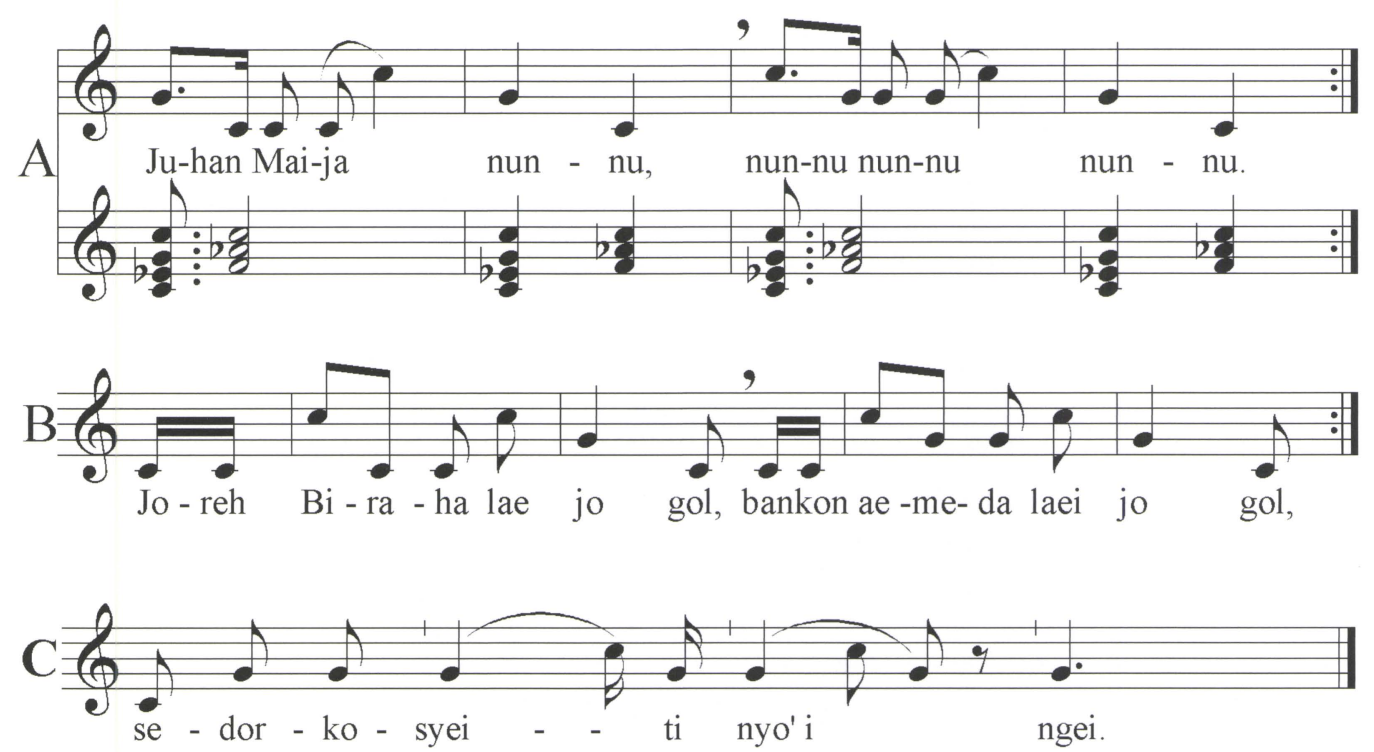

Esimerkki 5. A. Juhan Maijan joiku Koutokeinosta (Launis 1908: 467) edustaa alleelia $g^{-}{ }^{*} \alpha_{5 \rightarrow 1}$. Se koostuu neurosoinnuista Cm ja Fm (alaviivasto), joten C-solu on kaiken aikaa aktiivitilassa. B. Koutokeinosta on myös tämä Joreh Birehan joiku (Launis 1908: 277), jonka syntaksina on $g-* \alpha_{1 \rightarrow 1}$. C. Läntisten tundranenetsien eeppisen laulun viimeinen säe (Niemi 1998: 265) kuvaa koko lauluoppia: $g^{-*} \alpha_{1 \rightarrow 5}$. 
tilla ja päättyy sen alapuolella olevaan toonikaan: g- ${ }^{*} \alpha_{5 \rightarrow 1}$. Harvinainen on myös Joreh Biraha, joka alkaa ja päättyy dominantin alapuolisella toonikalla: g- $^{*} \alpha_{1 \rightarrow 1}$. Kumpikin joiku pitää C-hermon kaiken aikaa ärsytystilassa. Näin avoimelle alleelille löytyy vastine muun muassa läntisten tundranenetsien eeppisestä laulusta (esimerkki 5C). Jarkko Niemen (1998: 265) transkriptiossa jokainen säe on erilainen, mutta syntaksi on yksi: g- ${ }^{*} \alpha_{1 \rightarrow 5}$.

\section{Avoin beta-alleeli: * $\beta$}

Beta-alleeli ikään kuin koostuu luonnonsävelistä 6-7-8-9, jotka G-horisontissa vastaavat nousevia asteita 5-6-1-2 (g-b-c-d). Koska aste 3 puuttuu, alleelia ei voi modaalisesti määrittää, joten se pysyy avoimena ja esimodaalisena. Se eroaa alfa-alleelista siten, että siinä on aste 6, muttei astetta 3:

\begin{tabular}{|l|l|l|l|l|l|}
\hline Asteet: & $\mathbf{5}$ & $\mathbf{6}$ & $\mathbf{1}$ & $\mathbf{2}$ & $\mathbf{3}$ \\
\hline${\mathrm{g}-{ }^{*} \alpha:}^{*}$ & $\mathrm{~g}^{1}$ & & $\mathrm{c}^{2}$ & $\mathrm{~d}^{2}$ & $\mathrm{e}^{2}$ \\
\hline $\mathrm{g}-^{*} \beta$ & $\mathrm{g}^{1}$ & $\mathrm{~b}^{1}$ & $\mathrm{c}^{2}$ & $\mathrm{~d}^{2}$ & \\
\hline Luonnonsävelet: & $\mathbf{6}$ & $\mathbf{7}$ & $\mathbf{8}$ & $\mathbf{9}$ & $\mathbf{1 0}$ \\
\hline
\end{tabular}

Taiwanin yami-väestö on laulanut pyhän lentokalan pyyntikauden loppuessa rituaalilaulua, joka koostuu sävelistä as², ges², es². Yamit kuuluvat austronesialaisten kielten malaijo-polynesialaiseen haaraan, jonka lähisukulaisia elää Filippiinien pohjoisilla saarilla. Kun laulu kalibroidaan G-horisonttiin (esimerkki 6A), sävelet on määritettävä laskevasti asteiksi 1-6-5 eli säveliksi $\mathrm{c}^{2}-\mathrm{b}^{2}-\mathrm{g}^{2}$, jotka muodostavat alleelin $\mathrm{g}^{*} ß$ esiheksatonaalisen markkerin. Alleeli on niin avoin, että siitä voi johtaa heksatonaaliset kantamoodit g-IV, g-V ja g-VI, mutta myös pentatonaaliset g-LA ja g-MI. Pallosymboli ${ }^{\circ}$ osoittaa, että melodian ainoat sävelet ovat markkerin kolme säveltä. Näin avointa markkeria ei kuitenkaan voi enää liittää vain beta-alleeliin, joten se määritetään epsilonmarkkeriksi. Sen symbolissa pallosymboli jo sinällään riittää ilmaisemaan alleelirakenteen: $\mathrm{g}-{ }^{\circ} \varepsilon$.

Yleensä laulajat ovat valinneet beta-alleelista neljä tai viisi astetta, joten mukana on myös aste 2 (tässä d²) ja toisinaan ylädominantti $\mathrm{g}^{2}$. Taiwanilaisen lentokalan ylistyslaulun likeisenä paralleelina on Itä-Siperian tunguuseita edustavien evenien laulu esimerkissä 6B. Koska siinä on myös sävel $\mathrm{d}^{2}$, markkerisymboli ${ }^{\circ}$ poistuu syntaktisesta kaavasta. Muutoin syntaksi on g- $^{*} \beta_{6 \rightarrow 5^{5}}$. Beta-alleelin esiintyminen Itä-Aasian eveneillä, 
yameilla ja keeteillä (esimerkki 3C) saattaa viitata hyvinkin vanhaan syntaktiseen ratkaisuun. Evenit ovat tunguuseja, mutta heidän geeneissään ja kulttuurissaan on lainoja heihin sulautuneista jukagiireistä, joiden kulttuuri näyttäisi jatkuneen omalaatuisena pohjoisen Siperian periferioilla yli 20000 vuotta. Beta-alleeli on heille tyypillinen, mikä voidaan nähdä laulutarinan kolmisäkeestä esimerkissä 6C. Laulaja tukeutuu asteille 2-1-5, mutta käväisee korusävelin myös asteella 6. Melodia muuntuu kaiken aikaa, mutta metri on vakaa ja syntaksina on $g_{-}^{*} \Omega^{1 \rightarrow 1}$. Kaava on ominainen itäisen Aasian laulajille, mutta sitä löytyy muualtakin. Muun muassa Keski-Afrikan tasavallassa asuva baAka-väestö järjestää verkollapyyntiretkiä ja niitä edeltävän juhlan tanssilauluista yksi on esimerkkinä 6D. Voi miettiä, olisivatko baAkat voineet säilyttää syntaksin sukupolvesta toiseen, ja jos olisivat, niin silloin myös jukagiirit olisivat voineet tehdä saman. Mietiskely johtaa spekulointiin: olisivatko Aasiaan muuttaneiden varhaiset esivanhemmat jo voineet siirtää syntaksin $g_{-}{ }^{*} \beta^{1 \rightarrow 1}$ mukanaan Koillis-Afrikasta, ja olisivatko tietyt väestöt onnistuneet säilyttämään sen Itä-Aasiassa?

Toisinaan melodian moodin määrittäminen ei ole mutkatonta, mutta analyysin tekeminen neurosointujen avulla johtaa tulokseen, joka hankalissa melodioissa useinkin yllättää. Beta-alleeli ei näyttäisi pohjoissaamelaisilla olevan mitenkään luonteenomaista. Kuitenkin esimerkissä 7 on Guttur Nilla, jonka Armas Launis (1908: 663b) oli sijoittanut laskeville sävelille $\mathrm{d}^{2}-\mathrm{b}^{1}-\mathrm{g}^{1}$. Voitaisiinko siis ajatella, että kyse on luonnonsävellaulusta ja että tässä on vastine C:n ääneksille 9-7-6? Tällöin kuulokeskuksessa syntyy kolme neurosointua, $\mathrm{Gm}^{6}$, Esm ${ }^{6}$ ja $\mathrm{Cm}^{6}$, jolloin sitojasoluina ovat G-EsB. Kun dominanttina on nyt sävel $g$, syntaktisena rakenteena on käänteinen $g-i^{*} \beta^{2}{ }_{5}$. Ongelmaksi nousee se, että joiku kuullostaa ongelmattomalta ja täysin luontevalta.

Jos se G-horisontissa nuotinnetaankin kvarttia ylemmäksi $\left(\mathrm{g}^{2}-\mathrm{es}^{2}-\mathrm{c}^{2}\right)$, soluankkureiksi tulevat Es-As-C (esimerkki 7). Kun tutkana on g, se tukee vahvasti jokaista laulettua säveltä. Samalla havaitaan, ettei kyseessä olekaan luonnonsävelten tapaan järjestyvä beta-alleeli g- ${ }^{*} S^{5 \rightarrow 1}$, vaan c-mollin niin avoin alleeli, ettei sitä voi määrittää sen kummemmin luonnolliseksi kuin harmoniseksikaan, koska aste 6 puuttuu. Koska määritystä ei voi tehdä, ja koska samaan tapaan epäselviksi jääviä melodioita löytyy kaikkialta, olen päätynyt koodaamaan ne yhdellä syntaktisella kuvaajalla. Olen valinnut kreikkalaisen $\mu$-kirjaimen tarkoittamaan "mollin kaltaista"; tällöin symboli * $\mu$ tarkoittaa esiheksatonaalista alleelia, josta voi johtaa sekä harmonisen että luonnollisen mollin alleelit *III ja *IV. Tarkempaan analyysiin ei päästä. Esimerkin 7 lauluopillisena kuvaimena on siis $g_{-}^{*} \mu^{5 \rightarrow 1}$. Koska melodia on riippuva, lopullisena kaavana on $g-\pi^{*} \mu^{5 \rightarrow 1}$. Kyseessä ei siis ole lainkaan beta-alleeli vaan myy-alleeli * $\mu$ ! 

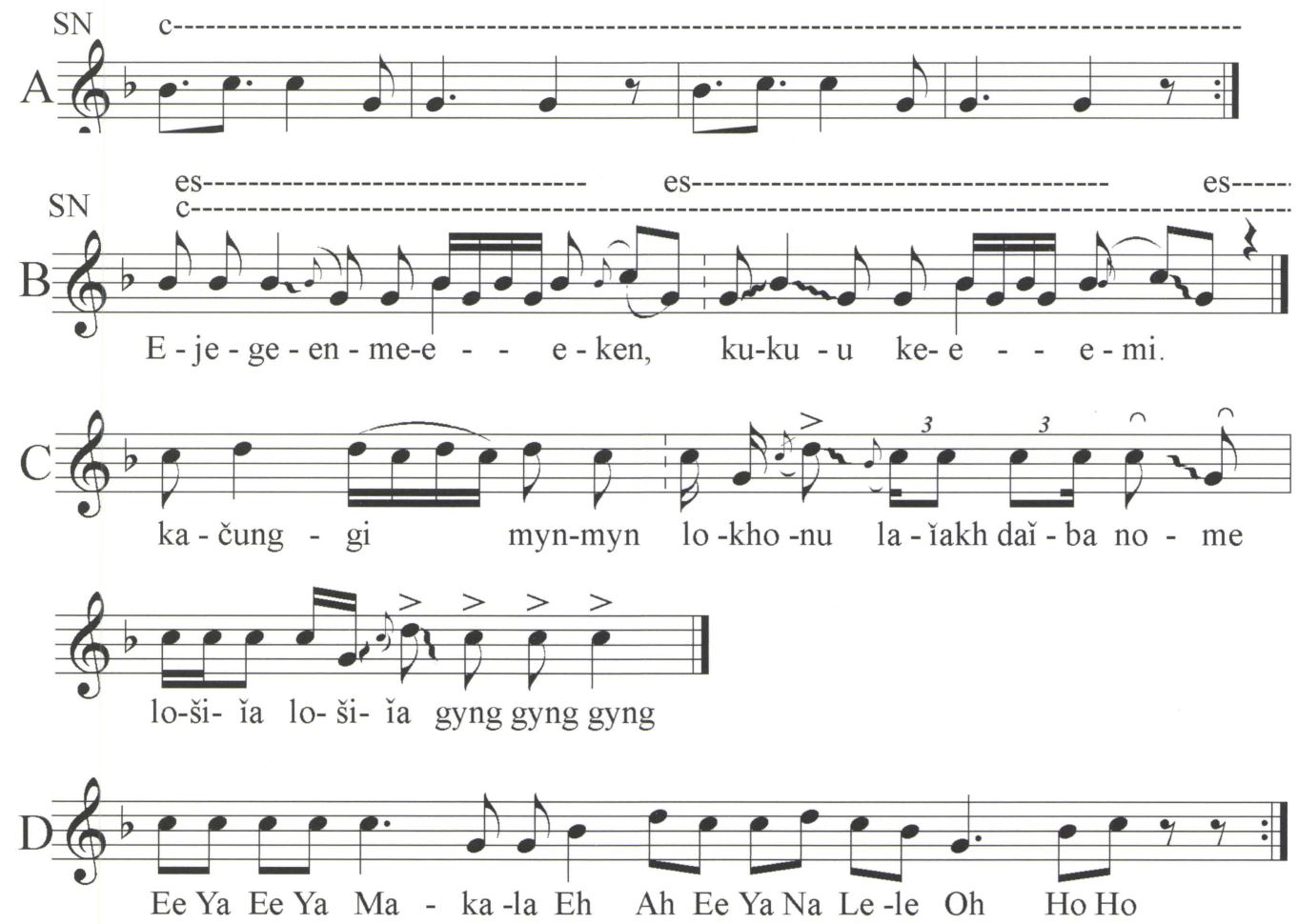

Esimerkki 6. Beta-alleelille g-* ${ }^{*}$ pohjautuvia sävelmiä. A. Taiwanin yami-kalastajien kalendaarilaulu (MTIP 1997: raita 2; nuotinnos kirjoittajan) koostuu mahdollisesti ß-alleelin esiheksatonaalisesta markkerista. Koska varmuutta ei ole, sävelikkö määritetään epsilonalleeliksi ja syntaksina on $g^{\circ}{ }^{\circ} \varepsilon_{6 \rightarrow 5}$. B. Tunguuseihin kuuluvien evenien laulussa (Šejkin 2002: 599, esim. 3a) on kolme säveltä, joista b-sävelen jännite purkautuu vasta säkeen lopussa melodian laskeutuessa toonikalta dominantille. Kukin sävel aktivoi C-solut, mutta b ja g myös Es-solut. Syntaksina on $g^{*}{ }^{*} \beta_{6 \rightarrow 5^{\circ}}$ C. Jukagiirien laulutarinan säkeet 2-4 (Ignateva \& Šejkin 1993, no. 13). Syntaksina on $g_{-*}^{*} \beta^{1 \rightarrow 1}$. D. Keski-Afrikan tasavallan baAka-väestön verkkopyyntiä edeltävään juhlaan kuuluva tanssilaulu Kisliukin (2001: 98) mukaan. Syntaksina on $g^{*} * \beta^{1 \rightarrow 1}$.

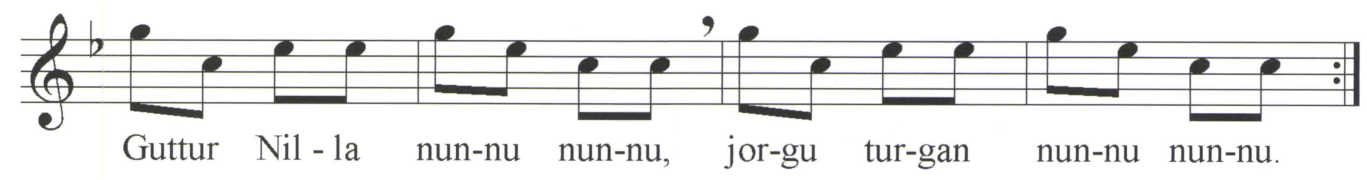

Esimerkki 7. Inarilainen joiku Guttur Nilla (Launis 1908: 663b) edustaa c-mollin avointa riippuvaa alleelia $g-\pi^{*} \beta^{5 \rightarrow 1}$. 
Hokkaidon ainujen karhukulttiin liittyvässä rituaalilaulussa (esimerkki 8) on kaksi erikoisuutta. Ensinnäkin sen alarivin tahtiin 4 ilmaantuu yksittäinen sävel es², joka ei kuulu g- ${ }^{*} ß$-alleeliin. Toisaalta havaitaan, ettei c-säveltä esiinny melodiassa ensinkään. Melodiaa ei saa sijoitettua G-horisonttiin kuin aloittamalla se säveleltä $\mathrm{g}^{2}$. Näin kuvattuna sävelten $\mathrm{g}^{2}, \mathrm{~d}^{2}, \mathrm{~b}^{1}$ ja $\mathrm{g}^{1}$ aktivoimat neurosoinnut ovat $\mathrm{Cm}$, Ebm ja $\mathrm{Gm}$. Melodia siis etenee ärsyttämällä d-sävelen aktivoiman $\mathrm{Gm}$-soinnun vahvimpia solupisteitä G, B ja D, mikä tarkoittaa, että sävelikkö on käänteinen g- $^{*} i \mathrm{~B}^{5}{ }_{5}$. Kuitenkin laulettu sävel es osoittaa, että laulajan mielessä oli alarivin neljän ensitahdin aikana ollut esimodaalisen beta-alleelin varhaisheksatonaalinen johdos g- $i \pi^{*} I V$, jossa sävel es on sen kolmas aste ( $\mathrm{g}-\mathrm{b}$-c-d-es). Sekin on käännös. Täten tämän betaaiholta näyttävän sävelmän syntaksi onkin odotettua monimutkaisempi, koska siinä tapahtuu modulaatio ${ }^{*} \beta \rightarrow{ }^{*} \mathrm{IV} \rightarrow{ }^{*} \beta$ ja alleelit ovat lisäksi riippuvia. Laulun syntaktinen mikrorakenne on g- $i \pi^{*} \beta^{5} \rightarrow \mathrm{g}-\dot{i} \pi^{*} I V^{5 \rightarrow 2} \rightarrow \mathrm{g}-i \pi^{*} \beta_{5}$. Beta-alleelin voi teoreettisesti ajatella laajenevan sekä LA-pentatonaalisuuden että mollimuotoisen heksatonaalisuuden (*III, *IV) suuntaan. Tämäkin melodia viittaa siihen, että ainut olivat suosineet esiheksatonaalista syntaksia, mikä erottaa ainujen lauluopin Kaakkois-Aasian ja Melanesian kehityksestä. Sävelmässä tapahtuu siis huomaamaton siirtymä esimodaalisesta modaaliseen ja takaisin. Jos yllä oleva syntaktinen kaava halutaan tiivistää yhdeksi moodiksi sivuuttamalla modulaatio ${ }^{*} \beta \rightarrow{ }^{*} \mathrm{IV} \rightarrow{ }^{*} \beta$, tuloksena on g- $i \pi^{*} \mathrm{IV}^{5} \rightarrow 5^{*}$ Tämä ei kuitenkaan anna tutkijalle samoja tietoja päätelmien tekoon kuin mikrotason syntaktinen määrite.

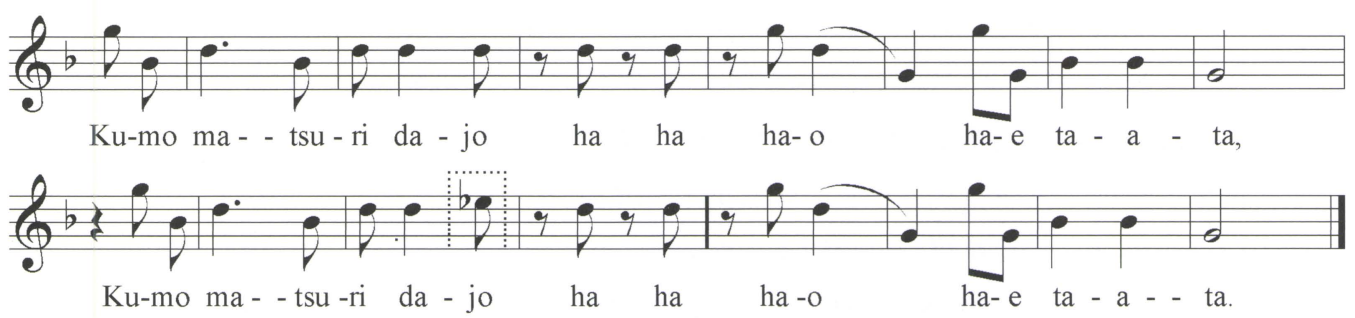

Esimerkki 8. Ainujen karhuriittiin kuulunut laulu (Kondou 1960: 14, nro 4) Sävelmä on riippuva ja käänteinen $g-¿ \pi^{*} \beta$, paitsi että alarivin neljä alkutahtia voidaan tulkita luonnollisen c-mollin käänteiseksi alleeliksi $g-i \pi^{*} I V$ eli laskevana g-es-d-b[-g]. Kuulokeskuksessa ankkurina on $C$, paitsi kun lauletaan sävel es ${ }^{2}$. Tutkaksi vahvin vaihtoehto on siis sävel g, joka tukee jokaista laulettua säveltä (myös es:ää). 


\begin{tabular}{|c|c|c|c|c|c|}
\hline Asteet: & 5 & 6 & 1 & 2 & 3 \\
\hline Lauletut sävelet: & $\mathrm{g}$ & $\mathrm{b}$ & c & $\mathrm{d}$ & $\mathrm{g}$ \\
\hline Hermosointu: & $\mathrm{Cm}$ & Ebn & $\mathrm{Fm}$ & $\mathrm{Gm}$ & $\mathrm{Cm}$ \\
\hline \multirow{6}{*}{$\begin{array}{l}\text { Soluvaste } \\
\text { (pystysuora) } \\
\text { ja } \\
\text { sidonta } \\
\text { (vaakasuora): }\end{array}$} & \multirow[t]{3}{*}{$\mathrm{G}$} & & & (G) & (G) \\
\hline & & Ges & ges+ & \multirow{3}{*}{$\mathrm{E}$} & \multirow{4}{*}{$\begin{array}{c}\mathrm{f} \\
\mathrm{Es}\end{array}$} \\
\hline & & & $\mathrm{F}$ & & \\
\hline & (Es) & ES & & & \\
\hline & \multirow[b]{2}{*}{ dest } & & (D) & (D) & \\
\hline & & & & & des \\
\hline \multirow{3}{*}{ Ankkuri: $\longrightarrow$} & (C) & $(\mathrm{C}+)$ & (C) & (c) & (C) \\
\hline & \multirow[b]{2}{*}{$\mathrm{A}^{+}$} & (B) & (b) & (B) & \multirow[b]{2}{*}{$\mathrm{A}+$} \\
\hline & & (as) & (As) & (ast & \\
\hline
\end{tabular}

Kuva 6. Avoimen beta-alleelin ( $g-b-c-$ d) vaste kuulokeskuksessa kalibroituna G-horisonttiin $(g-* \beta)$.

Menetelmän vahvuus näkyy esimerkin 8 avulla. Laulun olisi voinut nuotintaa myös siten, että aloitussävelenä olisi toonika $c^{2}$, päätössävelenä $c^{1}$ ja sävelikkönä $c^{2}$-g ${ }^{1-}$ $\mathrm{f}^{1}-\mathrm{es}^{1}-\mathrm{c}^{1}$. Kumpi ratkaisu siis on oikea? Jälkimmäisessä tapauksessa solukaista F olisi kuulokeskuksessa jatkuvasti ärsytystilassa. Sitä tukee parhaiten c-tutka, joten transkriptio olisikin C- eikä G-horisontissa ja moodina olisi luonnollinen c-*ß3. Jälkimmäinen tulkinta on siis väärä. Toisin sanoen 12 hermosolusta subharmonisiksi sarjoiksi järjestyvien neurosointujen avulla voidaan tunnistaa melodian synnyttämä soluankkuri ja täten määrittää melodian suhde G-horisonttiin ja lopulta tunnistaa sävelikkö, joka tässä sävelmässä voi olla vain g- ¿ $\pi^{*} \beta$ ja laajentuneena g- ¿ $\pi^{*} I V$. Usein tutkan voi määrittää melko turvallisesti ilman alitajuisen ankkurin määritystä, mutta maailma on täynnä januskasvoisia melodioita, joista ei tahdo saada otetta ilman tässä esitellyn menetelmän tukea. Kuvasta 6 näkyy solutason sidonta kuulokeskuksessa alleelin g- ${ }^{*} \beta$ yhteydessä. Esimerkissä 8 ei esiinny toonikaa (c), joten sidonta on hieman toisenlainen, mutta kuulokeskuksessa C:lle virittynyt solukaista on kaiken aikaa ärsytettynä ja muodostuu siis neuronaaliseksi ankkuriksi, jota parhaiten tukee g-tutka.

Ainu-melodia herättää kysymyksen onko joiussa beta-alleelia ensinkään? Toistaiseksi olen tunnistanut vain yhden (esimerkki 9), mikä viittaa siihen, että joikua luonnehtii "duurimainen" alfa-alleeli ${ }^{8}$. Tämä on kiinnostava yksityiskohta sen teorian valossa, jonka mukaan pohjoissaamelaisen joiun syntaksi palautuu Eurooppaan noin 40000 vuotta sitten saapuneiden ensimmäisten nykyihmisten laulusyntaksiin, ja että länsisaamelaiset ovat ainoana väestönä Euroopassa säilyttäneet sen (ks. Leisiö 2004). Armas Launis kirjasi beta-alleelin Norjan Kaarasjoella, jossa Siire Niilesin 20-vuotias Pitti-tytär joikasi "hyvän" nimismiehen (esimerkki 9A). Melodia rakentuu G-horisontissa sävelille g-b-c-d, jotka vastaavat sekä pohjasävelen c harmonisia 
ääneksiä 6-7-8-9 että samaisen c:n subharmonisia kuulosoluvasteita 6-7-8-9 eli F-D+' C-B (ks. kuva 2). Tässä joikaaja aineellisti teoreettisen g-tutkan laulamalla sen sekä aloitus- että päätössävelenä. Melodia säilyy kuitenkin yhtä avoimena $\left(\mathrm{g}-{ }^{*}{ }_{5 \rightarrow 5}\right)$ kuin vaikkapa Keski-Aasian tofa-laulu 9B ja Etelä-Amerikan yekuana-väestön laulu (esimerkit 9B ja 9 $\mathrm{C}^{9}$ ).
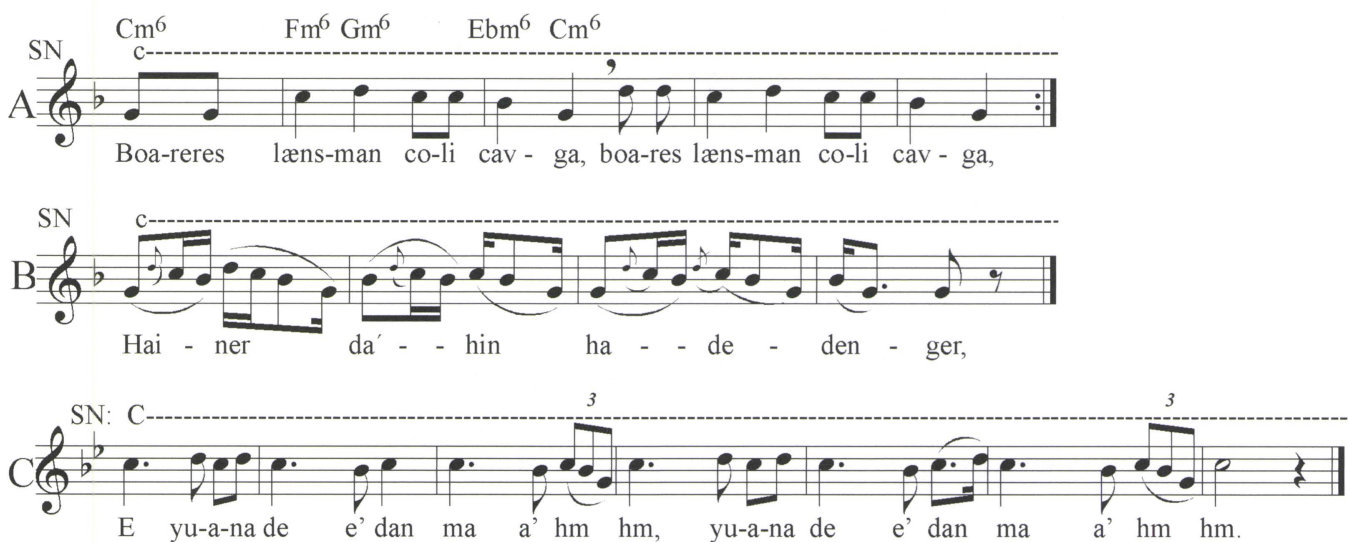

Esimerkki 9. Beta-alleelille $g-* \beta$ pohjautuvia sävelmiä. A. Tunturisaamelainen Boarres lænsman Norjan Kaarasjoelta Launiin (1908: 521) mukaan. Viivaston yläpuolella olevat sointumerkinnät osoittavat, mitä neurosointuja lauletut sävelet aktivoivat. Myös neurosointu Gm6 aktivoi C-solun, joten C toimii tässä joiussa solutason ankkurina ( $S N=$ sitojaneuroni). Syntaksina on $g^{*}{ }^{*} \beta_{5 \rightarrow 5^{\prime}}$. B. Altain turkkilaisiin kuuluvan Tofa-kansan juhlalaulu (Šejkin 2002: 681) etenee alleelin $\mathrm{g}_{-}^{*} \beta_{5 \rightarrow 5}$ sävelillä. Melodia synnyttää samat neurosoinnut Cm, Fm, Gm ja Ebm kuin edellinen. C. Yekuana-väestön laulun säepari Venezuelasta (MYI 1975: raita A1) kirjoittajan nuotintamana. Teksti on vain kirjoittajan arvio. Syntaksina on $g^{*} \beta^{1 \rightarrow 1}$.

Jurij Šejkinin laajahkosta sävelmäkokoelmasta paljastuu, että Siperiassa ß-alleeli on suhteellisen tavallinen. Kuvan 5 avulla voidaan ymmärtää, että tämä alleeli on grammaattiselta muodoltaan aina $\mathrm{g}-{ }^{*} §$ riippumatta siitä, miten yksinkertaisella tai monimutkaisella tavalla itse sävelmä esitetään (vrt. esimerkit 9A ja 9B). Samasta on kyse myös kieliopin tasolla. Jos kielelle on ominaista järjestys subjekti-verbi-akkusatiivimuotoinen objekti ("minä näen suden"), on aivan sama toteuttaako puhuja tämän säännön kuiskaamalla, huutamalla, nopeasti, hitaasti, korkealla tai matalalla äänellä, nauraen tai itkien. Kummallakin alueella esitystapa ja kommunikointia ohjaava syntaksi ovat erilliset alueet. Siperian osalta beta-alleelin levikki näkyy taulukossa (kuva 7). 


\begin{tabular}{|c|c|}
\hline $\begin{array}{l}\text { Alleelin } \\
\text { asteet: }\end{array}$ & Väestö, kielikunta sekä lähde Šejkinin si vu- ja sävelmänumerona: \\
\hline$g-b(8):$ & $\begin{array}{l}\text { Tšuktši (PS): 623,1. Nanai (Tng): 591,1. Udehe (Tng): 594,4. Evenki } \\
\text { (Tng): 600,5. Saha (T): 600,2. 601,4. Nganasan (U): 606,2. Selkuppi } \\
\text { (U): } 659,1 .\end{array}$ \\
\hline$g-b-c(11):$ & $\begin{array}{l}\text { Eskimo (PS): 652, 3. Tšuktši (PS): 624,2. Kereekki-tšuktši (PS): 629, } 4 \text {. } \\
\text { Tuva (T): 551,1; 552,2. Tufa (T): 590,1. Eveni (Tng.): 599,3a; 633,7. } \\
\text { Jukagiiri (PS): 607,7. Burjatti (M): 609,5. Nenetsi (U) } 707,1 \text {. }\end{array}$ \\
\hline$g-b-d(1):$ & Nanai (Tng): 592,5 . \\
\hline$g-b-c-d(14)$ & $\begin{array}{l}\text { Tšuktši (PS): } 535-536,2.623,2 \text {. Udehe (Tng): } 518,1 . \text { Evenki (Tng): } \\
600,6.666,5.668,2 . \text { Burjatti (M): } 609,7.701,1 \text { ja } 2.702,1 . \text { Jugi: } 662,3 \text {. } \\
\text { Tuva (T): } 697,1 . \text { Tofa (T): } 681,1.683,1 .\end{array}$ \\
\hline
\end{tabular}

Kuva 7. Avoimen beta-alleelin ( $g-{ }^{*} \beta$ ) G-horisonttiin transponoituja ilmentymiä Siperiassa Šejkinin (2002) kokoelmasta poimittuna. Kielikunnista PS = paleosiperialainen; Tng = tunguusilainen; $T=$ turkkilainen; $U=$ uralilainen ja $M=$ mongolinen. Jugi tarkoittaa keeteille sukua ollutta jeniseiläistä, nyt jo kuollutta kansaa.

Kuva 7 paljastaa, että avoin beta-alleeli on ollut käytössä laajalti Siperiassa eskimoilta nenetseille ja Taimyrilta Altaille ja Amurille. Se koskettaa Siperian kaikkia laajoja kielikuntia aina paleosiperialaisia väestöjä myöten. Voi siis olettaa, että siellä se on ollut käytössä hyvinkin kauan, mikä on kiintoisaa ja jopa omituista juuri pohjoissaamelaisesta näkökulmasta. Siperian turkkilaiset jakuutit olivat vaeltaneet 1300-luvun tienoilla Baikal-järven alueelta koilliseen eli nykyiseen Jakutiaan. Ajautuessaan erilleen muista turkkilaisista he olivat säilyttäneet monia vanhakantaisia piirteitä. Kuitenkin juuri heidän keskuudessaan beta-alleelista näyttäisi muodostuneen kansallisen identiteetin erityisen vahva symboli. Koko Euraasiassa on vain kaksi väestöryhmää, joille se on keskeinen identiteettitekijä, Siperiassa jakuutit ja Länsi-Euroopassa keltit. Kummatkin väestöt käyttävät sitä lauluopillisesti samaan tapaan, vaikka esitystavat eroavatkin.

Langnerin harmonisen teorian kannalta modaalinen juuri g-VI on kiintoisa sen vuoksi, että se paljastaa kaksi pitkään ärsytystilassa olevaa samanaikaista solukaistaa, jotka ovat C ja B. Tämä tarkoittaa, että juurella voisi olla kaksi vaihtoehtoista tutkaa (f ja g) ja kaksi modaalista määritystä (g-VI ja f-* $\alpha$ eli f-b-c-d). Teoreettisista borduunoista kuitenkin g tukee laulettuja säveliä vahvemmin kuin f. Esimerkin 10 Skotlannin gaelinkielisestä laulusta havaitaan, että kummankin rivin lopulla tapahtuu sävelkulku $b^{1}-c^{2}-f^{1}$. Laulettaessa $b^{1}$ kuulokeskuksessa syntyy neurosointu Ebm6, jossa C-kaista on 


\begin{tabular}{|c|c|c|c|c|c|c|c|}
\hline Asteet: & 5 & 6 & 1 & 2 & 3 & 4 & 5 \\
\hline Lauletut sävelet: & $\mathrm{g}$ & $\mathrm{b}$ & $\mathrm{c}$ & $\mathrm{d}$ & $\mathrm{e}$ & $\mathrm{f}$ & $g$ \\
\hline Hermosointu: & $\mathrm{Cm}$ & Ebm & $\mathrm{Fm}$ & $\mathrm{Gm}$ & $\mathrm{Am}$ & $\mathrm{Bm}$ & $\mathrm{Cm}$ \\
\hline \multirow{7}{*}{$\begin{array}{l}\text { Soluvaste } \\
\text { (pystysuora) } \\
\text { ja } \\
\text { sidonta } \\
\text { (vaakasuora) }\end{array}$} & \multirow[t]{4}{*}{$\mathrm{G}$} & & & (G) & \multirow{3}{*}{ Fis +} & (G) & (G) \\
\hline & & \multirow[t]{3}{*}{ Ges) } & \multirow{4}{*}{$\frac{\text { gest }+ \text { }}{F}$} & & & & \\
\hline & & & & & & (F) & (f) \\
\hline & & & & (E) & (E) & & \\
\hline & (ES) & (ES) & & & & (es) & (ES) \\
\hline & \multirow[b]{2}{*}{ dest } & & (D+) & (D) & (d) & & \\
\hline & & & & & & Des & dest \\
\hline \multirow[t]{5}{*}{ Ankkuri: $\longrightarrow$} & (C) & (C) & (C) & (c) & (C) & & (C) \\
\hline & \multirow{4}{*}{$\mathrm{A}^{+}$} & & & & & $\mathrm{H}^{+}$ & \\
\hline & & (B) & (b) & (B) & $(\mathrm{b}+)$ & (B) & \\
\hline & & & & & (A) & & $\mathrm{CA} \pm$ \\
\hline & & (as) & (As) & (ast) & & & \\
\hline
\end{tabular}

Kuva 8. Kantamoodin g-VI sävelet (vaakarivi ylinnä) ja niiden aktivoimat neurosoinnut. Tummennetut vaakarivit osoittavat, mitkä kaistat pysyvät pitkään aktiivitilassa. Ne muodostavat sitojia, joista vahvin on ankkuri. Tässä ankkurina on C-kaista, jota parhaiten tukee g-tutka, mutta sävelten b ja d soidessa vahvimmin aktivoituu B-solu, jota taas tukisi parhaiten f-tutka.

subharmonisena alapisteenä 7 (ks. kuva 8). Laulajat siirtyvät c:lle, mikä aktivoi neurosoinnun Fm6 (F-As-C-D+2), jossa F-solu on alapisteinä 3-6-12. Niinpä laulajat seuraavat tätä reittiä ja laulavat sävelen $\mathrm{f}$, jonka aktivoimat solut B-Des-F-G ${ }^{+}$sitovat laulun lopun sen uuteen alkuun, joka käynnistyy g:llä. Kuvasta 8 näkyy, että B-solu aktivoituu vahvasti, kun lauletaan sävel b ja ilmeisesti sen vaikutuksesta laulajat alitajuisesti hakeutuivat sävelelle f. Tämän he tekivät toonikan c kautta, sillä kummankin sävelen soidessa F-solu on prominentti. Toisin sanoen G-horisontissa etenevä sävelkulku, jonka finalis on $b$, d tai $\mathrm{f}$, on neuronaalisesti B-ankkurin kontrolloima ja tässä valossa voidaan todeta, että laulun numero 10 kaltaisten melodioiden loppua ei hallitse g-VI, vaan niissä tapahtuu modulaatio f-pohjaiseen alleeliin. Koska sävelet b, c ja d aktivoivat myös As-kaistan, on mahdollista päätellä, ettei alleeli ole $\mathrm{f}^{-}{ }^{*} \alpha(\mathrm{f}-\mathrm{b}-\mathrm{c}-\mathrm{d})$, vaan $\mathrm{f}-{ }^{*} \beta$ (f-as-b-c-d). Täten riippuvan melodian syntaktinen kuvaaja olisi g- $\pi \mathrm{VI}_{5} \leftrightarrow \mathrm{f}-{ }^{*} \beta_{5}$. Oletus johtaa kuitenkin spekulointiin niin kauan kuin tietoa ei ole as-sävelen esiintymisestä. Analyysissä lähdetäänkin siitä, että tuo f-pohjainen aines on avoin alfa-alleeli. Syntaksina on $\mathrm{g}-\pi \mathrm{VI} \mathrm{I}_{5} \leftrightarrow \mathrm{f}{ }^{*}{ }^{*} \beta_{5}$. Kuulija kokee väkevästi tämän modulaation, joka onkin laulun varsinainen koukku. Brittein saarten kelteillä VI kantamoodi esiintyy siis ainakin kahdenlaisena syntaksina. Usein se hallitsee koko laulua, jolloin keskellä olevasta modulaatiosta huolimatta se sekä aloittaa että päättää sävelmän. Toisinaan taas käy kuten esimerkissä 10. Melodian keskellä kantamoodi VI moduloituu sekunnilla alas alfa-alleeliksi: $\mathrm{g}-\mathrm{VI} \rightarrow \mathrm{f}-{ }^{*} \alpha$, mikä näkyy esimerkin 10 yllä olevassa kaavassa. 

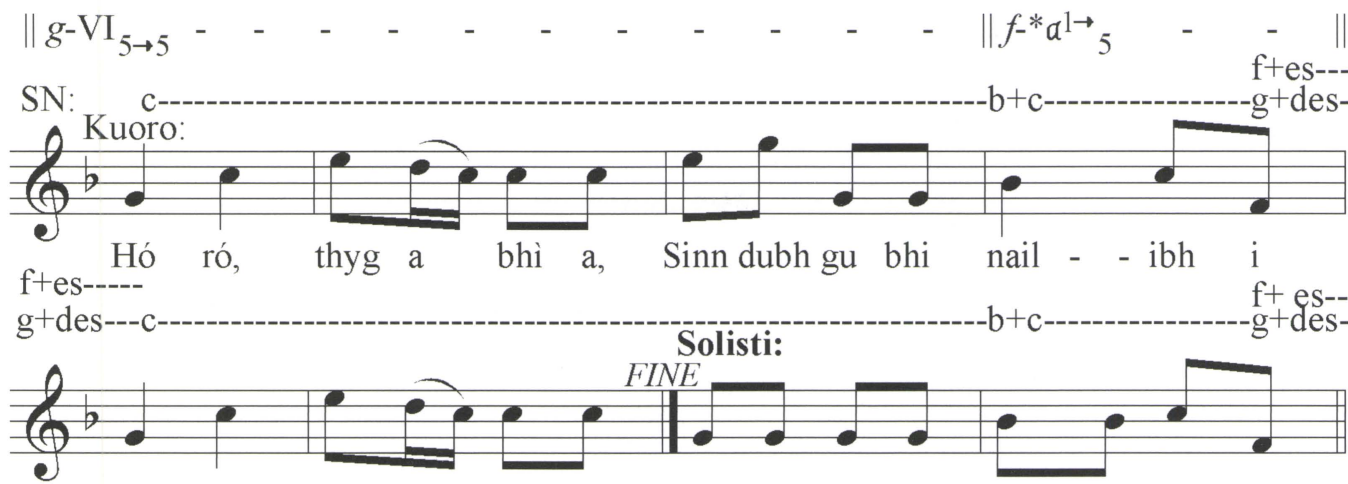

Hó ró, thyg a bhì a, AIL - EIN, AIL-EIN, 'S FHAD' DO CHAD-AL,

Esimerkki 10. Kelttiläinen kankaanvanutuslaulu Shawn (1977: 103) mukaan Länsi-Skotlannista. Laulajat käyttävät moodin g-VI kaikkia säveliä. SN tarkoittaa sitojaneuronia. Mikrotasolla tapahtuu dominantin siirtymä g:ltä f:lle, mitä prosessia ylinnä oleva kaava kuvaa. Kaava pätee sekä ala- että ylärivillä.

Tampereen yliopiston musiikintutkimuksen laitoksen arkistossa on äänite jakuuttimiesten laulannasta: esilaulajan kahdeksanmooraista noususäettä seuraa esilaulajan ja kahden "jälestäjorottajan" yhdessä esittämä laskusäe. Rakenne on kuten kalevalamittaisessa vuorolaulussa. Esitys kestää noin 12 minuuttia, ja siitä paljastuu jakuuttilaulun moni peruspiirre kuten kurkunpää-äänten vahva käyttö, korostunut tremolo sekä viehtymys pysytellä moodin asteilla 1, 2 ja 3.

Äänite alkaa esilaulajan lämmittelyllä. Hän käyttää vokaalipitoisia sekreemeitä ajan edetessä parlando rubato. Johdanto kestää 3'20" ja on metrisesti jäsentymätön. Jokaisen säeparin aikana lauletut sekreemit, sävelten järjestys ja rytmiikka eroavat edellisistä säepareista, mutta peruskuvio on sama (ks. esimerkin 11A lopputahdissa annettua pohjakaavaa) ja kolmen käytetyn sävelen tasot säilyvät vakaina.

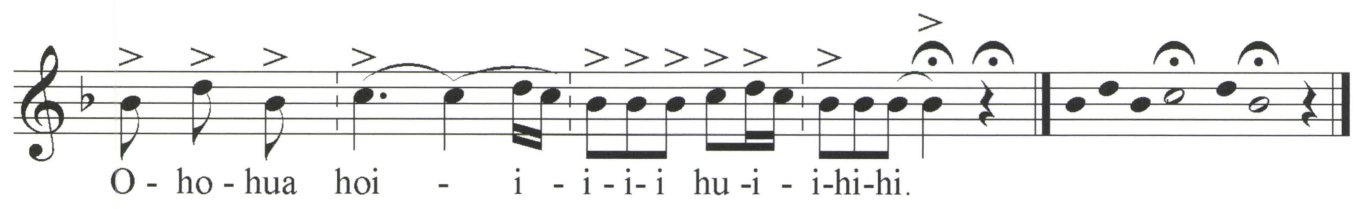

\section{Esimerkki 11A.}


Johdanto on jännittynyt, mutta jännittyneisyyden syy on epäselvä. Skottilainen esimerkki saattaa kuitenkin paljastaa syyn. Laulaja säestäjineen leikittelee pitkään alleelin $\mathrm{f}^{-} \alpha$ asteilla 1-2-3 (b-c-d), jotka kuitenkin kuulija sijoittaa oppimaansa laajempaan säveljärjestelmään g-VI. Toisin sanoen opitun ja siis muistia hallitsevan moodin g-VI vaikutuksesta tässä pitkään etenevä f- ${ }^{*} \alpha$ luo jännitteen yhtäältä odotusten ja toisaalta laulun todellisuuden välille. Jännitteen olisi purkauduttava, mutta niin ei tapahdu. Näin ollen johdannon syntaksi noudattaa kaavaa: $\mathrm{f}^{*} \alpha^{1} \rightarrow \mathrm{g}^{*}{ }^{*} \mathrm{~S}^{1} \rightarrow \mathrm{f}-{ }^{*} \alpha^{1}$. Siinä ß-osuuden muodostaa esimerkin 11A toinen tahti.

Runsaan kolmen minuutin jälkeen esilaulaja aloittaa kahdeksan mooran metriin sidotun laulun, jonka hän käynnistää painokkaasti johdannossa heikoksi jääneeltä toonikasäveleltä c. Seuraavien minuuttien aikana esilaulaja ja kuoro rakentavat gtutkan varassa vähin erin VI moodin niin, että pitkän esityksen lopulla esilaulajan ja kuoron vuorottelu on kuten esimerkissä 11B. Olen sijoittanut sahankielisen tekstin sijaan vastaavasti tavutetun säkeen Lemminkäisen surma -laulusta.

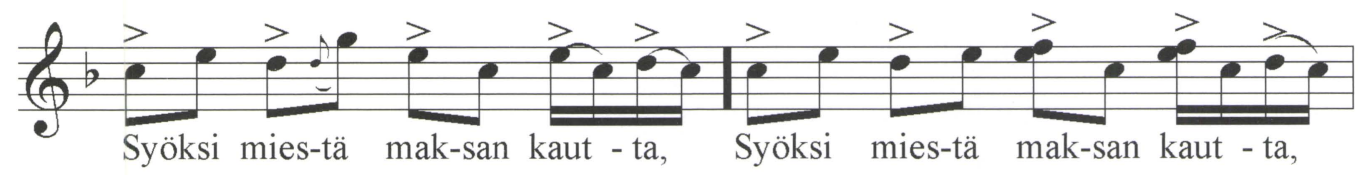

\section{Esimerkki 11B.}

Laulu siis alkoi alleelin $\mathrm{f}^{*} \alpha$ kolmella sävelellä (b-c-d), ja yli yhdeksän minuutin laulamisen jälkeen ryhmä oli koonnut VI moodin kaikki sävelet. Pitkän esityksen syntaksin keskeiset ainekset voidaan kiteyttää kaavaan: $\mathrm{f}^{*} \alpha^{1} \rightarrow \mathrm{g}-{ }^{*} \beta \rightarrow \mathrm{f}-{ }^{*} \alpha^{1} \rightarrow \mathrm{I}$ g${ }^{*} \mathrm{IV}^{1} \rightarrow \mathrm{g}-\pi^{*} \mathrm{VI}^{1}$. Tässä siis ainekset ovat kuten kelttilaulussa, mutta päinvastaisessa järjestyksessä.

Melko tavanomaisesti eeppisen tarinan kerronta etenee Jakutiassa myös esimerkin 12 tavalla, jossa ovat mukana sävelet b-c-d-e (asteet 6-1-2-3) ja rivi muodostuu kahdesta 8 mooran säeparista.

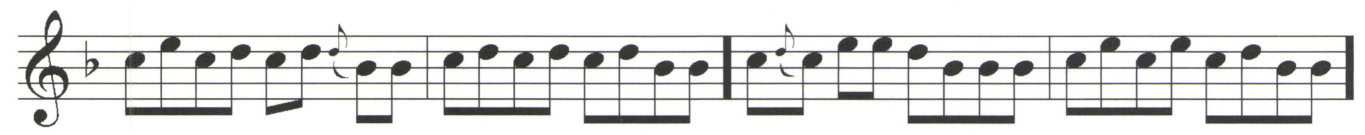

Esimerkki 12. Kaksi säeparia jakuuttien kertovasta Olonho-laulusta. (JMF s.a.: raita A3). 
Esimerkin 12 melodiasta voi havaita, että päätössävelenä on säännöllisesti b neurovasteenaan Es-molli. Laulaja tulee siihen aina d-säveleltä, jonka vasteena kuulokeskuksessa on Gm. Kummankin soidessa B-solut ovat aktivoituneet vahvasti, mikä aivan luontevalla tavalla johdattaa melodian päätössävelelle b. Vaikka esimerkin 12 laulu voidaan määrittää syntaksikuvaimella g-VI ${ }_{6^{\prime}}$, melodian hienoanalyysi paljastaa edellä jo esitellyn modulaation $\mathrm{g}-\mathrm{VI}^{1} \leftrightarrow \mathrm{f}^{*} \alpha^{1}$. Toisin sanoen esimerkin 12 jakuuttisesitys eroaa esimerkin 10 kelttiläislaulusta vain siten, ettei alku- ja loppusävelenä ole dominantti vaan toonika. Syntaksin perusainekset ovat samat: $\mathrm{g}-\mathrm{VI} \leftrightarrow \mathrm{f}-{ }^{*} \alpha$. Äkkipäätä voisi ajatella, ettei samuus voi olla geneettistä, sillä eihän Itä-Siperian jakuuteilla voi olla yhteyksiä Länsi-Euroopan keltteihin. Tarkkaan ottaen yhteys on kuitenkin olemassa, sillä kummankin väestön (siis esikantaturkkilaisten ja ennen kelttejä eläneiden paleoeurooppalaisten) esivanhemmat ja etenkin naiset ${ }^{10}$ olivat erkaantuneet toisistaan samasta keskiaasialaisesta populaatiosta. Mutta aikaero on kymmeniä tuhansia vuosia, joten lauluoppien lähihistorian kannalta samuudella ei ole tässä merkitystä. Samuuden aiheuttaakin yhteinen neuronaalinen syy: valittu sävelkombinaatio. Beta-alleelin johdannaisena olevan VI moodin ja $\alpha$-alleelin vuorottelu dominanttien $g$ ja f varassa synnyttää samat vasteet kuulokeskuksessa ja saa kuulijoissa aikaan samanlaiset solureaktiot (ks. kuvat 6 ja 8). Kummallakin alueella modulaation $\mathrm{g}$-VI $\leftrightarrow \mathrm{f}-{ }^{*} \beta$ seurauksena laulettu sävel $\mathrm{d}$ muuttuu alleelin $\mathrm{f}^{*} \alpha$ aikana asteeksi 3.

Ihminen on lajina yksi, mutta eri väestöt ovat kehittäneet mitä erilaisimpia musiikillisia traditioita. Näyttää kuitenkin siltä, että alitajuisen syntaksin tasolla lajiominainen samuus tulee esille. Saharan eteläpuolisen Afrikan baAkat ovat kehittäneet monimutkaisen polyfonisen laulun, jolla he ovat säestäneet tanssijoita. Michelle Kisliuk (2001: 80-84) kuvaa muun muassa Mama Angeli -nimistä sävelmää, jossa on kaksi sopraano- ja kaksi alttostemmaa sekä basso. Hän tajusi, että laulun perusrivin kertautuvana aineksena oli "kolme 12 iskun ryhmää" eli säe toistettiin kolmella eri tavalla ja näin syntyi toistuva säekolmikko. Kisliuk oli tehnyt vaikuttavan tutkimuksen ja tarkat nuotinnukset, mutta musiikkianalyysiin hän ei ryhtynyt. Kun polyfonista kudosta erittelee siirtymäteorian avulla (esimerkki 13), tulos on kiintoisa: sopraano- ja alttostemmat noudattavat samaa syntaksia, joka taas on osittain sama kuin edellä keltti- ja jakuutti-lauluissa. Kussakin kolmessa "12 iskun ryhmässä" on oma dominanttisävelensä, joka laskee kaavan $\mathrm{g}^{1}-\mathrm{f}^{1}-\mathrm{c}^{1}$ mukaan. Niiden pohjalta jokainen laulettu rivi noudattaa syntaksia g- ${ }^{*} \mathrm{~B}^{1} \rightarrow \mathrm{f}-{ }^{*} \mathrm{VI} \rightarrow \mathrm{c}-{ }^{*}{ }^{*} \beta_{5}$. Oleellista on siis modulaatioketju ${ }^{*} \beta \rightarrow{ }^{*} \mathrm{VI} \rightarrow{ }^{*} \beta$. Bassoääni noudattaa eri syntaksia, jossa vain kolmannessa 


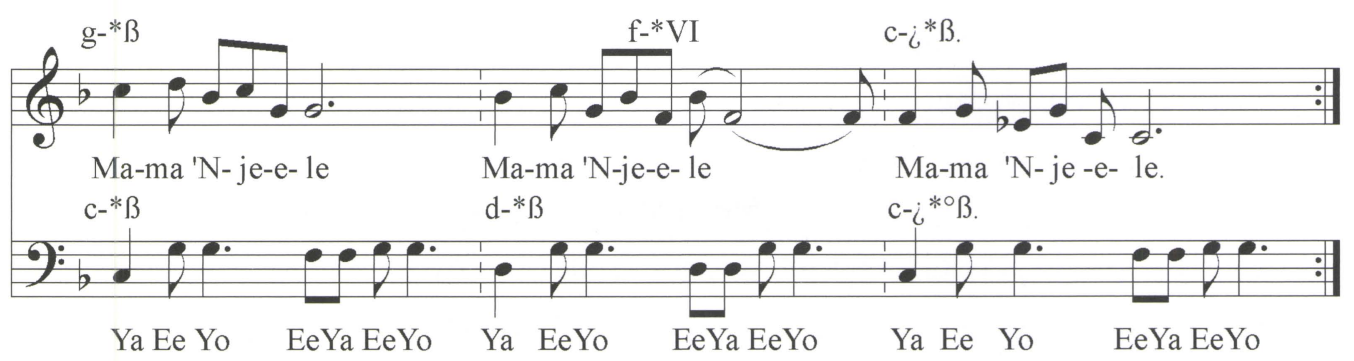

Esimerkki 13. BaAka-väestön viisiäänisen tanssilaulun sopraano- ja bassostemma Kisliukin (2001: 83) mukaan G-horisonttiin transponoituna. Aktiiviset dominantit ja niille rakentuvat alleelit on merkitty äänten yläpuolelle.

eli säkeen päättävässä "ryhmässä" alleeli on sama kuin neljällä naisäänellä: c-* ${ }_{5} \rightarrow d-$ ${ }^{*} \beta \rightarrow c-i^{*} \beta^{2}$.

Akat (yakat) eli baAkat kuuluvat valtavan Niger-Kongon kieliperheen benue-kongolaisten bantukielten puhujiin. Kielellisesti he ovat sukua niinkin etäisille väestöille kuin Tansanian swahilit sekä Etelä-Afrikan vendat ja zulut. Beta-alleelin käyttö ja sen vuorottelu VI moodin aihion kanssa niin, että dominantti siirtyy g:ltä alas f:lle yhdistää syntaktisella tasolla jakuutit, keltit ja akat. Samuus ei suinkaan viittaa laulajien musiikkioppien suoranaiseen sukulaisuuteen. Sen sijaan se viittaa kahteen seikkaan. (1) Beta-alleelin kuudes aste b johdattelee neuronaalisista syistä laulajat helpostikin dominantilta g dominantille $\mathrm{f}$. Esimerkissä 13 sopraano siirtyy aihioon $\mathrm{f}-{ }^{*} \mathrm{VI}$ vasta toisen tahdin keskellä, kun muut kolme stemmaa jo sen alussa. Kaikkien neljän laulamat äänet osoittavat, että toisessa tahdissa aihiona on *VI eikä * $\beta$. (2) On siis mahdollista olettaa beta-alleelin ja aihion *VI olevan niin luonnonmukaisia, että ne olivat kuuluneet ihmisen musiikkiopin syntaksiin jo ennen muuttoa Afrikasta muille mantereille 80000-60000 vuotta sitten. Kiintoisa kysymys kuitenkin on se, miksi ihmiset ovat kaikkialla pitäytyneet alleeliperusteisessa syntaksissa laajentamatta esimerkiksi betaalleelia modaaliseksi aihioksi *VI. Osavastaus löytyy tietenkin melodisten soitinten kehittymisestä musiikin osaksi, mutta selitys on vaillinainen.

Dolgaanit ovat Taimyrin niemen eteläosassa asuva kansa, joka kehittyi 1700-luvulla ennen kaikkea jakuuttien, nganasanien ja venäläisten sulautumana. Dolgaanin kielessä keskeisimpänä aineksena on jakuutti. Sama koskee musiikkia, jossa on aineksia myös nganasaneilta ja tunguusinaapureilta, ennen kaikkea evenkeiltä ja eveneiltä (Alekseeva 1989: 108). Jakuuttien lauluoppiin palautuu myös sekä betaalleelin että äärimmäisen tremolon käyttö. Esimerkin 14 melodian voi ensinäkemäl- 
tä tulkita nousevan beta-alleelista niin, että toonika (c) esiintyy vain ohimenevästi aloitussävelen tremolossa. Muutoin melodia koostuu b:n, d:n ja e:n vuorottelusta ja loppukuvio muodostuu tritonuksesta b-e-b. Melodia on kuitenkin problemaattinen: miten sijoittaa se G-horisonttiin? Jos sen sijoittaa kuten esimerkissä 14A, lauletut sävelet ovat b-c-d-e ovat edellä olevien melodioiden mallin mukaan kuten asteet 6-1-23. Melodia pitää kaiken aikaan aktiivitilassa solukaistat B ja C sekä suurimman osan aikaa kaistat As ja Ges. Nämä toimivat siis sitojina. Vahvin sitojista on kuitenkin B-kaista, jota f-ankkuri tukee optimaalisesti. Vaikeudet alkavat tästä. Alleelina on siis $\mathrm{f}^{*} \alpha^{1 \rightarrow 1}$. Jos näin todella olisi, alleeli olisi F-horisontissa ja sen rakenne olisi $\mathrm{f}-\mathrm{b}$ c-d-e, josta laulaja käyttää vain säveliä $\mathrm{b}^{1}-\mathrm{d}^{2}-\mathrm{e}^{2}$ (asteet 1-3-4). Tulkinta on kuitenkin mahdoton, sillä kaikissa (esi)heksatonaalisissa säveliköissä asteiden 4 ja 5 välillä on kokosävelaskel. Tässähän sävelten $\mathrm{e}^{2}$ ja f² välissä on puolisävelaskel.

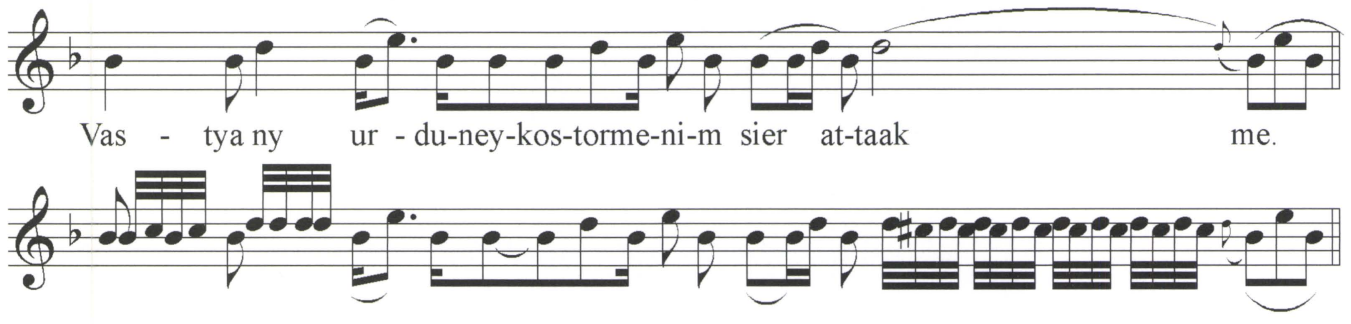

Esimerkki 14A. Dolgaanien eeppisen laulun säe Alekseevan (1989: 105) mukaan. Ylärivillä näkyy melodia ilman koristeellisia tremoloita, alarivillä on sama laulajan tuottamien tremolojen kera.

Melodia on mietittävä uudelleen lähtemällä siitä, että kuulokeskuksessa esimerkin 14A vahvin sitoja on B-solu, jota tukee teoreettinen f-tutka. Se on siirrettävä sekuntia korkeammalle ja näin G-horisontissa lauletut sävelet ovat mahdollisia vain kantamoodin g-II asteina 5-6-1 eli sävelinä $\mathrm{g}^{1}-\mathrm{h}^{1}-\mathrm{c}^{2}$ (ks. kuva 2). Tässä ei siis olekaan kyse beta-alleelista, vaan kantamoodista II. Se aina käänteinen, ja koska käytetyt sävelet ovat tuon moodin heksatonaalinen markkeri, melodian syntaksin todellisena kuvaajana on g- $i^{\circ} \mathrm{II}_{5 \rightarrow 5}$. 


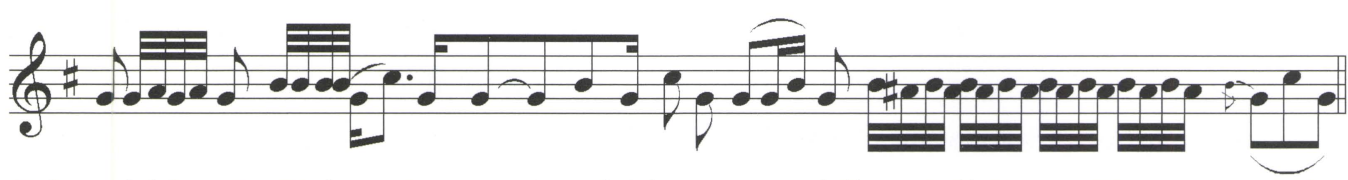

Esimerkki 14B. Dolgaanien eeppisen laulun säe uudelleen tulkittuna. Kyseessä on aina käänteisenä esiintyvän toisen moodin alleeli, tarkemmin sanottuna sen esiheksatonaalinen markkerig-h-c\#.

Kun dolgaani-sävelmää katsoo tarkemmin havaitsee, että aihioon g-`II kuulumaton $\mathrm{a}^{1}$ on seuraus laulajan kurkunpäällään toteuttamasta tremolosta. Sama koskee säveltä a\# . Nämä sävelet kuuluvat siis esitykseen, mutta eivät sitä ohjaavan lauluopin syntaksiin. Tässä käänteisyys näkyy siinä, että lauletut sävelet tukevat teoreettista tutkaa g, joka

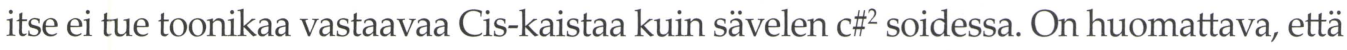
sävelen g neurosoinnussa $\mathrm{Cm}$ ja sävelen c\# neurosoinnussa Fism on neljä kaistaa, jotka värähtelevät kummankin aktivoimana samaan aikaan: $\mathrm{G}, \mathrm{A}, \mathrm{Es}=\mathrm{Dis}$ ja Des=Cis:

laulettu sävel ja neurosointu:

tutka ja sen neurosointu:

\begin{tabular}{|c|c|c|}
\hline $\mathrm{g}: \rightarrow$ & C & Es \\
\hline h: $\rightarrow$ & & $\mathrm{E}$ \\
\hline $\mathrm{C \#}: \rightarrow$ & & $\mathrm{Dis}^{+}$ \\
\hline $\mathrm{g}: \rightarrow$ & C & Es \\
\hline
\end{tabular}

$\mathrm{g}: \rightarrow \quad \mathrm{C}$
Es

$\begin{array}{lll}\mathrm{A}^{+} & & \mathrm{f} \\ \mathrm{a} & \mathrm{H} & \mathrm{f}^{+} \\ \mathrm{A} & \mathrm{h} & \end{array}$

A $h \quad$ Fis

$\mathrm{A}^{+}$ $\operatorname{des}^{+}$

$\mathrm{Cis}^{+}$

Cis des $^{+}$

Palattakoon vielä yleiskuvaan, joka näyttäisi avautuvan tarkasteltaessa avointen alleelien ilmentymiä Euraasian pohjoisilla alueilla. Tunturisaamelaista joikua luonnehtii selkeästi alfa-alleeli ja sen johdoksena g-*I. Beta-alleeli on ollut tyypillinen Siperian laululle ja tämän syntaktisen kehityskulun yhtenä huipentumana on jakuuttien lauluoppi. Beta-alleelin suosionnousu näyttäisi siis tapahtuneen Siperiassa jo hyvin kauan sitten. Mutta miksi Euroopassa ennen kaikkea keltit ovat sitä suosineet? Aiemmin olen uumoillut, että syynä oli läntisessä Keski-Euroopassa (Alpeilla, Ranskassa, Belgiassa) asuneiden paleoeurooppalaisten musiikki, jota sekä maanviljelys että luonnonsävelpuhaltimet kuten pitkähuilu ja alppitorvi olivat leimanneet jo kivikauden lopulla (Leisiö 2007b: 262-263). Näissä soittimissa sai helposti soimaan luonnonsävelet 4-10, jolloin G-horisontissa kyse on juuresta g-VI (luonnonsävelet c-e-g-b-c-d-e). Ne olivat siirtyneet myös laulajien käyttöön. Kun indoeurooppalaiset alkoivat noin 5500-4500 vuotta sitten muuttaa noille seuduille Tonavaa myöten idästä, alkoi kehkeytyä paikallisten valtakulttuureiden ja määrältään vähäisten mutta teknologialtaan edistyksellisten muuttajien sekakulttuureita, joita nykyisin kutsutaan kelttiläisiksi. Läntinen kantaindoeurooppa alkoi muuntua Alppien ympäristössä kelttiläiseksi kantakieleksi, jota myös alkuperäi- 
set asukkaat alkoivat puhua. Vaikka paikalliskielistä vain baski on säilynyt omaan aikaamme, laulussa säilyi runsaasti alkuperäisväestön piirteitä kuten jodlaus, alppitorvi, kantamoodin VI ja sen aihioiden käyttö sekä sekreemien (kuten ho'ró, thyg a bhi a esimerkissä 10) runsaus, mikä edelleenkin luonnehtii sekä kelttien että länsisaamelaisten laulua. Kelttiäistyessään indoeurooppalaiset omaksuivat muinaiseurooppalaisten syntaktisia piirteitä, joita keltit siirsivät Brittein saarille jo ennen ajanlaskun alkua.

\section{Jälkimietteitä}

Siirtymäteorian keskeinen piirre on sävelmänsisäisten modulaatioiden ja transpositioiden seuraaminen ja tätä kautta lauluopin syntaksin määrittäminen. Olen seurannut kuvien avulla sidontaa: mitkä solut pysyvät ärsytystilassa vaikka lauletut sävelet vaihtuvat. Yleensä solukaistoista yksi pysyy pidempään ja vahvempana aktiivitilassa kuin muut. Sitä kutsutaan ankkuriksi: melodia rakentuu siten, että se kieppuu kiinnittyneenä yhteen ankkuriin. Tämä synnyttää alitajunnassa kokemuksen jatkuvuudesta ja auttaa laulajaa pysymään "oikeassa vireessä". Ankkuri ei kuitenkaan pysy kauan aktiivisena. Mitä monimutkaisempi laulu, sitä nopeammin se vaihtuu toiseksi. Toisena päämääränä onkin löytää se sävel, joka tukee optimaalisesti melodiaan kuuluvia säveliä ja mainittuja ankkureita. Tämä sävel ei aina edes kuulu laulettuihin säveliin, mutta se on teoreettisesti määritettävissä. Aiemmin kuvittelin, että tällainen tutka löytyy kuulokeskuksesta, mutta sellaista ei löydy. Tutkasävel on teoreettinen ja se toimii analyysin apuvälineenä siinä kuin tähtitieteessä teleskooppi. Sen synnyttämän neurosoinnun kaistat ovat samoja kuin laulettujen tai soitettujen sävelten aktivoimat kaistat. Optimaalinen tutka on moodin tai alleelin dominantti, joka luonnollisissa säveliköissä tukee ennen kaikkea toonikaa. Käännetyissä säveliköissä tilanne on nurinpäin: lauletut sävelet tukevat teoreettista tai todellista borduunaa eli tutkaa.

Siirtymäteorian avulla monitulkintaisetkin melodiat on mahdollista sijoittaa Ghorisonttiin. T.G.H. Strehlow (1971) julkaisi Australian alkuperäisväestön 2-sävelisiä melodioita transponoimalla ne sävelille $\mathrm{c}^{2}$ ja $\mathrm{a}^{1}$, joka on finalis. G-horisonttiin kirjoitettuna ne asettuvat säveliksi es ${ }^{2}$ ja c ${ }^{2}$, jotka ovat jonkin alleelin asteet 3 ja 1 (esimerkki 15). Säeparit päättyvät aina toonikaan, mutta mistä alleelista on kyse? Vaihtoehdot ovat g-III, g-IV tai g-V (vrt. esimerkki 1). Tämän kaltaisen alleelin ilmaisen aina kreikkalaisella $\lambda$-kirjaimella, joten melodian syntaksina on g- ${ }^{*} \lambda^{3 \rightarrow}{ }_{1}$. 


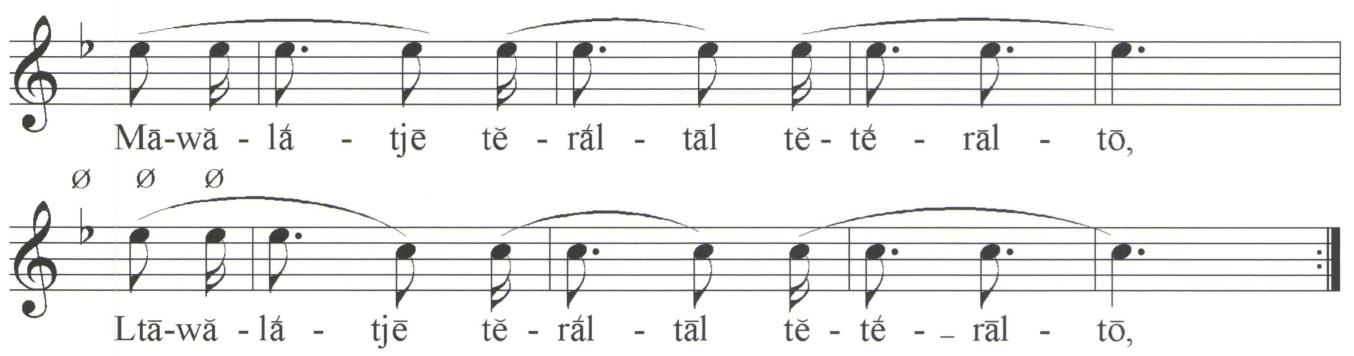

Esimerkki 15. Keskiaustralialaisen laulun kaksi säettä Strehlowin (1971: 21) mukaan Ghorisonttiin sijoitettuna.

Kun siirtymäteoriaa sovelletaan menetelmätasolla, melodialiikkeiden logiikka saadaan esille soittamalla ankkureiden vasteet tutkasävelellä. Yllä olevissa esimerkeissä ankkuri ei juuri muutu joten myöskään tutka ei muutu. Kuitenkin maailman lauluston valtaosa on sellaista, jossa ankkuri ja sen mukana teoreettinen tutka siirtyvät jonkin periaatteen mukaan paikasta toiseen. Näin tapahtuu mm. tunisialaisessa maqāmissa (esimerkki 16), jonka pohjalla on universaali heksatonaalinen syntaksi $\mathrm{g}-\mathrm{IV}^{2} \leftrightarrow \mathrm{d}-\mathrm{V}^{1}$.
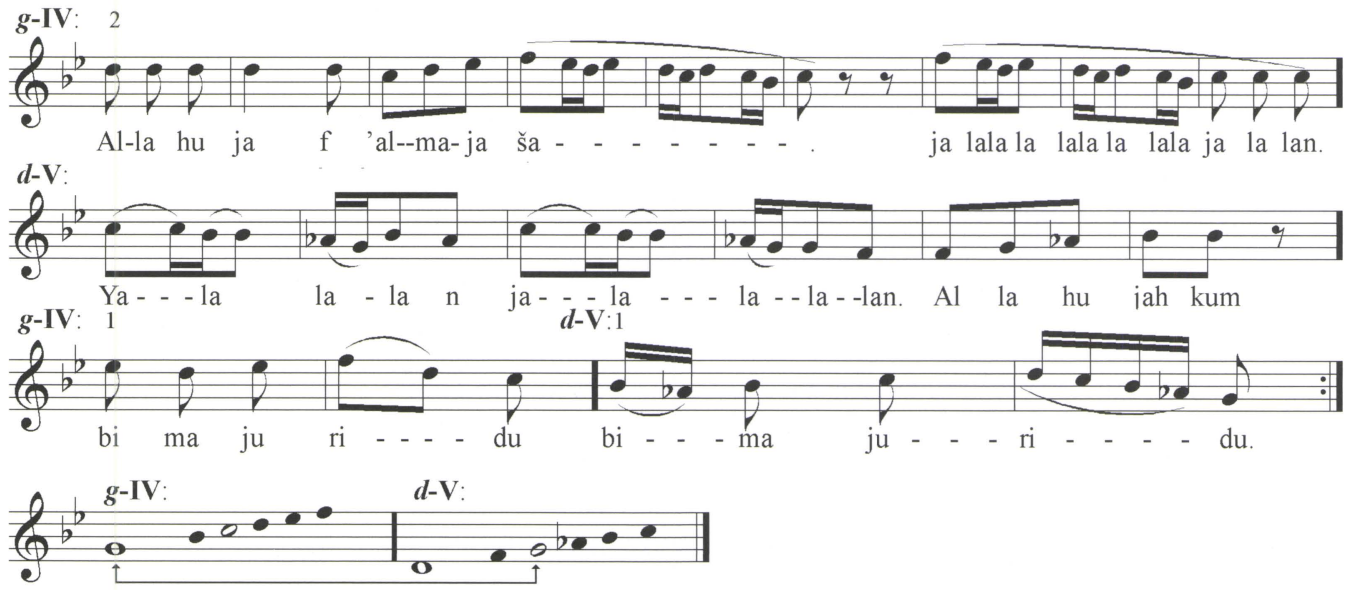

Esimerkki 16. Tunisialaiseen taidemusiikkiin kuuluvan sarjan ensimmäinen taite (D'Erlanger 1959: 595, nro IX) pohjautuu moodien g-IV ja d-V vuorottelulle. Vuorottelevat moodit näkyvät alinna. Aloitussävelen d neurovasteena on Gm ja päätössävelen g vasteena on $\mathrm{Cm}$, joten aloittava dominantti muuntuu lopussa toonikaksi. 
Lopuksi on kysyttävä: miksi heksatonaalisuus? Vastaus piillee kuulokeskuksessa. Sävel g synnyttää soluvasteen G-Es-C-A+-f-des ${ }^{+}$. Jos tämä subharmoninen sarja muunnetaan fysikaalisiksi säveliksi syntyy sarja d-b-g-e-c-as. Ollaan siis G-horisontissa ja syntyy VI moodia vastaava sävelikkö g-b-c-d-e-g. Alapiste 11 aktivoituu siinä määrin heikosti, ettei sen sävelvastinetta as esiinny yhdessäkään kuudesta kantamoodissa mutta se toimii alituisesti luontevana nivelenä modulaatioissa, siis sellaisissa, joissa esimerkiksi siirrytään C-duurista F-molliin tai As-duuriin. Asteiden g ja b (5 ja 6) välissä ei siis tapahdu vahvaa aktivoitumista, ei myöskään asteiden 3 ja 5 (e ja g) välissä. Jälkimmäiseen tilaan laulajat ovat kuitenkin lisänneet asteen 4 (f), mutta se vaatii dominantin hetkellistä nousua g:1tä c:lle. Heksatonaalisuus näyttää siis nousevan suoraan kuulokeskuksen aktivoitumisperiaatteesta.

\section{Viitteet}

1 Indoeurooppalainen kantakansa asusti vielä 6000 vuotta sitten Uralin eteläpuolen, Dneprin ja Mustanmeren välisellä aroalueella paimentolaisina, kauppiaina ja metallin jalostajina. Heidän siirryttyään Länsi-Euroopan ja Pohjois-Intian välisille alueille kantakielestä eriytyivät mm. slaavilaiset, germaaniset, balttilaiset, romaaniset ja kelttiläiset kielet kuten myös kreikka, armenia sekä indo-iranilaiset kielet kuten sanskrit, hindi, persia, osseetti ja kurdi. (Ks. Carpelan \& Parpola 2001.)

2 Kun värähdyksen jakso (kestoaika eli periodi) lyhenee, niin värähtelyn taajuus eli frekvenssi vastaavasti kasvaa. Taajuus kertoo kuin monta jaksoa toteutuu yhden sekunnin kuluessa ja taajuuden mittayksikkönä on hertsi $(\mathrm{Hz})$.

3 Esimerkiksi alapisteiden $1 / 8$ ja $1 / 9$ väli voidaan muuntaa senteiksi laskemalla logaritmisesti suhteen 9/8 laajuus:

$(\log 9-\log 8) \times$ vakio $3986=(0,95-0,90) \times 3986=204$ centtiä eli ellistä. (Ks. Leisiö 1988: 130 131.)

4 Merkitsen syntaksin symboleihin toonikan $c^{2}$ ja sen yläpuolella olevat asteet yläindeksillä, kun taas toonikan alapuolella olevat asteet 6, 5, 4, 3 jne. alaindeksillä: $g^{-*} \alpha^{3 \rightarrow 1}, g^{-*} \alpha^{1 \rightarrow}{ }_{5^{\prime}} g^{-*} \alpha^{5 \rightarrow}{ }_{5^{\prime}}$ $g^{*} \alpha_{6 \rightarrow 5^{\prime}} g^{-*} \alpha_{5 \rightarrow 5}$ jne.

5 Keetit ovat paleosiperialainen väestö, jonka esivanhemmat olivat tuoneet tonaalisen kielensä ajanlaskun alussa Minusinin laaksoon Kiinan suunnalta (Janhunen 2002, 186).

6 Laskentamalli on suhteellinen ja vain suuntaa-antava. Kullekin 12 alapisteelle saadaan sen energiaa kuvaava suhteellisen arvo sen mukaan, että pohjasävelen aktivoiman ensimmäisen solun energiaksi määritän 100, jonka logaritminen vastine on 2,0. Sen myötäaktivoima solu $1 / 2$ saa arvokseen 100/2, jonka logaritminen arvo on 1,70 ja kaistan 1/3 arvo on 1,52. Näin jatketaan, kunnes päädytään 12. alapisteeseen. Kun 12. alapisteen sarjassa pohjasävelen vaste esiintyy kerrannaisineen neljästi, sen logaritminen energia-arvo saadaan laskemalla kunkin neljän alapisteen arvot yhteen. Tulokseksi saadaan 6,20. Alapiste 3 saa kerrannaisineen summa-arvon 3,7, alapiste 5 kerrannaisineen saa summa-arvon 2,3. Lopulta alapisteen 7 arvo on 1,2 , pisteen 9 arvo on 1,1 ja pisteen 11 arvo on 0,96 . Vahvin arvo on siis 6,20 ja heikoin on 0,96 . Kun borduuna soi, se aktivoi täsmälleen saman sarjan samoin suhteellisin aktiviteettiarvoin.

7 Hermosolujen aktivoimilla solu(kaisto)illa 3-6-12 ei tietenkään ole sama periodi. Kuulokeskus kuitenkin tunnistaa ne samoiksi, koska ne ovat saman perusperiodin subharmonisia jaonnaisia $1 / 3,1 / 6,1 / 12$. 
8 Alfa-alleelin duurimaisuus ei johdu sen sisäisestä olemuksesta vaan kulttuurisista assosiaatioista Euroopassa, jossa on jo kauan ollut melodisia ja sointuja synnyttäviä soittimia. Oppimisen kautta ehdollistuneet soitinperäiset kokemukset ovat johtaneet siihen, että alfa-alleeli koetaan ikään kuin duurin asteiksi 5-123. (Vrt. soitinsäestyksellinen nykyjoiku.)

9 Vrt. aiempi virheellinen tulkintani (Leisiö 2007b: 296, kuva 38).

10 Nykyihminen syntyi nykytiedon valossa Koillis-Afrikassa ja levittäytyi sieltä mantereen muihin osiin. Naisten DNA-analyysi osoittaa, että Afrikassa oli kolmen naisen geeniperimässä tapahtunut mutaatio, joten Afrikassa oli neljä äitilinjaa: L0, L1, L2 ja L3. Ihmisen siirryttyä Afrikasta Lähi-Itään miesten mukana oli vain L3-linjan naisia. Näin kaikki Afrikan ulkopuolella syntyneet naiset ovat saman afrikkalaisen äidin tyttäriä. Uuden ajan alussa käynnistynyt orjakauppa Amerikoihin muutti rajusti tilannetta.

\section{Kirjallisuus}

Alekseeva, G. G. (1989) "Muzykal'nyı̆ fol'klor Dolgan." Muzykal'naja etnografija Severnoŭ Azii. Vypusk 10. Toim. Jurij I. Šě̌kin. Novosibirsk. Ss. 99-108.

Carpelan, Christian \& Parpola, Asko (2001) "Emergence, contacts and dispersal of Proto-Indo European, Proto-Uralic and Proto-Aryan in archaeological perspective." Early Contacts between Uralic and IndoEuropean: Linguistic and Archaeological Considerations. Ed. Christian Carpelan, Asko Parpola \& Petteri Koskikallio. Helsinki: Mémoire de la Société Finno-Ougrienne 242. Ss. 55-150.

Densmore, Frances (1922) Northern Ute Music. Washington: Smithsonian Institution. Bureau of American Ethnology. Bulletin 75.

D’Erlanger, Rodolphe (1959) La Musique Arabe. Tome sixième. Paris: Librairie Orientaliste Paul Geuthner.

Fodor, István (1998) "Uralian-Indo-European Contacts." The Roots of Peoples and Languages of Northern Eurasia I. Ed. Kyösti Julku \& Kalevi Wiik. Turku: Societas Historiae Fenno-Ugricae. Ss. 28-35.

Hauser, Michael (1992) Traditional Greenlandic Music. Acta Ethnomusicologica Danica 7. Københagen: Forlaget Kragen.

Helmholtz, Hermann L. F. von (1863) Lehre von den Tonempfindungen als physiologische Grundlage für die Theorie der Musik. Braunschweig: Friedrich Vieweg \& Sohn.

Huovinen, Erkki (2002) Pitch-Class Constellations. Studies in the Perception of Tonal Centricity. Turku: Acta Musicologica Fennica 23.

Häusler, Alexander (1998) "Überlegungen zum Ursprung der Indogermanen." The Roots of Peoples and Languages of Northern Eurasia. Ed. Kyösti Julku \& Kalevi Wiik. I. Turku: Societas Historiae Fenno-Ugricae. Ss. 36-52.

Ignateva, T. I. \& Yurij I. Šejkin (1993) Obrazcy muzykal'nogo folklora verkhnekolumskikh yukagirov. Yakutsk: Centr Etnomuzykovedčeskikh Issledovaniı̌ Severnoŭ Azii.

Janhunen, Juha (1996) Manchuria, An Ethnic History. Helsinki: Memoires de la Société Finno Ougrienne 222. JMF: Iz jakutskogo muzykal'nogo fol 'klora. Melodija: D 030639-40.

Kaeppler, Adrienne L. (1983) "Polynesian Music and Dance." Musics of Many Cultures. An Introduction. Ed. Elizabeth May. Berkeley-Los Angeles-London: University of California Press. Ss. 134-153.

Kisliuk, Michelle (2001) Seize the Dance! BaAka Musical Life and the Ethnography of Performance. Oxford-New York: Oxford University Press.

Kondou, Kyoujirou (1960 Ed.) Ainu no Uta. Shinjuku-ku Tokyo: Ainu Minyou Kenkyukai.

Launis, Armas (1908 toim.) Lappische Juoigos-Melodien. Suomalais-ugrilaisen Seuran Toimituksia XXVI. Helsingfors. 
Langner, Gerald (2007) "Jaksollisen signaalin aika-analyysi kuulojärjestelmässä: sävelkorkeuden, sointivärin ja harmonisuuden hermovasteet.". Etnomusikologian vuosikirja 19. Toim. Markus Mantere \& Heikki Uimonen. Ss. 213-235.

Leisiö, Timo (1988) Kansanmusiikintutkijan perussanastoa. Tampereen yliopisto: KPL Julkaisuja 12.

Leisiö, Timo (2004) "Sadan joiun salat. Teoria sävelmassojen liikuttelusta pohjoissaamelaisessa luonnonsäveljoiussa". Etnomusikologian vuosikirja 16. Toim. Marko Aho \& Antti-Ville Kärjä. Ss. 81-112.

Leisiö, Timo (2007a) "Introduction to Transition Hypothesis and the Universal Typology of Song Grammars". Vokal folkemusikk verden rundt: Studies in Global Vocal Traditions. Ed. Irene Bergheim. Trondheim: Tapir forlag. Ss. 11-55.

Leisiö, Timo (2007b) "A Comparative View on Germanic and Slavonic Hexatonal Song Grammars." Etnomusikologian vuosikirja 19. Toim. Markus Mantere \& Heikki Uimonen. Ss. 237-299.

Lükő, Gábor (1964) "Zur Frage der Musikkultur in der slawischen Urzeit." Studia Slavica Academiæ Scientiarum Hungaricx. Tomus X: 3-4. Ss. 237-289.

Lükő, Gábor (1965) "Vestiges indo-européens dans le folklore musical des peuples finno-ougriens." Études finno-ougriennes II: 1, ss. 35-66.

MTIP (1997) Sounds from Nature's Bosom - Music of Taiwan Indigenous Peoples. Sounds of Cathay, Volume 11. Republic of China.

MVY (1975) Music of the Venezuelan Yekuana Indians. Recorded by Walter Coppens, Barbara Brändli, Jean François Nothomb. Folkways Ethnic Records FE 4104. New York.

Niemi, Jarkko (1998) The Nenets Song. Tampere: Acta Universitatis Tamperensis 591.

Shaw, Margaret Fay (1977) Folksongs and Folklore of South Uist. Oxford: Oxford University Press.

Šejkin, Jurij I. (2002) Istorija muzykal'no ̌ kul'tury narodov Sibiri. Moskva: Rossiı̌skaja Akademija Nauk. Vostočnaja Literatura RAN.

Zarlino, Gioseffo (1983) On the Modes. Part Four of Le Institutioni Harmoniche. Translated by Vered Cohen, Ed. Claude V. Palisca. New Haven and London: Yale University Press. 